\title{
Article \\ Exploring the Impact of Electronic Commerce on Employment Rate: Panel Data Evidence from European Union Countries
}

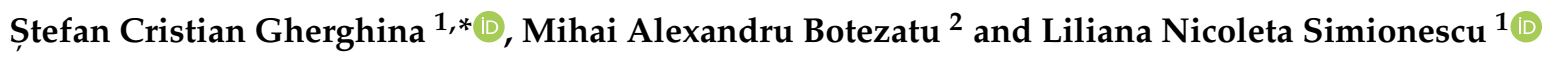 \\ 1 Department of Finance, Faculty of Finance and Banking, Bucharest University of Economic Studies, \\ 010374 Bucharest, Romania; liliana.simionescu@fin.ase.ro \\ 2 Department of Informatics, Statistics and Mathematics, School of Computer Science for Business \\ Management, Romanian-American University, 012101 Bucharest, Romania; \\ botezatu.mihai.alexandru@profesor.rau.ro \\ * Correspondence: stefan.gherghina@fin.ase.ro; Tel.: +40-741-140-737
}

Citation: Gherghina, S.C.; Botezatu, M.A.; Simionescu, L.N. Exploring the Impact of Electronic Commerce on Employment Rate: Panel Data Evidence from European Union Countries. J. Theor. Appl. Electron. Commer. Res. 2021, 16, 3157-3183. https://doi.org/10.3390/jtaer16070172

Academic Editor: Danny C. K. Ho

Received: 2 August 2021

Accepted: 11 November 2021

Published: 18 November 2021

Publisher's Note: MDPI stays neutral with regard to jurisdictional claims in published maps and institutional affiliations.

Copyright: (c) 2021 by the authors. Licensee MDPI, Basel, Switzerland. This article is an open access article distributed under the terms and conditions of the Creative Commons Attribution (CC BY) license (https:// creativecommons.org/licenses/by/ $4.0 /)$.

\begin{abstract}
The objective of this study is to explore the impact of electronic commerce on employment rate for a sample covering the whole 27 Member States of the European Union (EU-27), from 2010 to 2019. Moreover, this research explores the clusters of nations with reference to electronic commerce adoption and employment rate dynamics. The outcomes of cluster analysis show that Western Europe reveals the most developed e-commerce marketplace in EU-27, shown by Internet accessibility and high penetration rate of digital tools, and the lowest figures are registered in the Eastern part of Europe. Furthermore, the empirical findings of the panel data fixed-effects and the generalized least squares regressions suggest that electronic commerce influences employment rate positively. By including country-level control variables (real GDP growth rate, research and development expenditure, employed ICT specialists, enterprises with Internet access), the outcomes reveal that one percentage change in enterprises' total turnover from e-commerce sales, enterprises' turnover from web sales, and enterprises with e-commerce sales of at least $1 \%$ turnover will increase employment rate by $0.205,0.258$, and 0.350 percentage points. Furthermore, the econometric evidence from the method of moments quantile regression models with fixed effects reinforces our findings. Enterprises' total turnover from e-commerce sales and the percentage of enterprises with e-commerce sales of at least $1 \%$ turnover positively influence employment rate for all quintiles, but in the case of enterprises' turnover from web sales, the effect is positive only for the quintiles ranging from $0.5-0.8$.
\end{abstract}

Keywords: electronic commerce; employment rate; panel data; k-means clustering; fixed effects; method of moments quantile regression

\section{Introduction}

Technological development, automation, and digitalization are becoming more widespread in all areas of activity, causing some areas of the population to have lost their jobs recently, causing great concerns among people who often ask: Will a computer or a robot replace humans for many jobs? Will digitalization decrease vacancies? Will unemployment increase? Will the employment rate decrease?

Given that the indicators that influence employment rate reflect the ability of the economy to generate opportunities and employment solutions for the population [1], they must be the goal of government or private policies, to influence the economic development of countries or regions under sustainability principles. This thus meets the requirements of sustainable development as formulated worldwide [2], in order to ensure a better employment rate, as well as a higher standard of living. At the European Union (EU) level, the EU's 2020 Agenda is Europe's strategic 10-year program (2010-2020) to ensure the sustainable, competitive, and smart development of EU economies [3], by supporting and developing the information and communications technology (ICT) presented in the "digital agenda for Europe" [4]. 
Even if the idea of creating more jobs with the expansion of digitalization seems to be conflicting, [5] shows that digital literacy and e-skills are now mandatory for the workforce. These requirements, together with additional investments in high-speed Internet, are priorities of the Agenda 2020 as they have positive effects on employment rate. Therefore, government policies, and those of local, zonal, or sectoral administrations, are highly important in dealing with these very sensitive issues for the population.

E-commerce represents 10-15\% of total retail sales in Europe, its strong growth over the past decade being accelerated by the COVID-19 pandemic [6]. Nevertheless, due to the health and economic crises in the past two years, the issue of employment rate, the opportunities of employment under such circumstances, along with the survival of businesses have become supplementary pressing matters for all EU countries. E-commerce, together with its collateral activities (online payment platforms, freight transport-courier, related software products, IoT tools that require implementation and maintenance, including manufacturing) have largely protected savings, jobs, and the employment rate. As such, cloud computing, big data, and e-commerce remain major priorities aimed to spur progress within industries, as well as to increase the demand for innovative jobs expertise [7]. The influence of e-commerce is anticipated to generate jobs directly and indirectly, and to disregard jobs that no longer require social involvement. Indirect job conception will ensue through augmented demand and efficiency [8]. Thus, the impact of e-commerce on employment is imperative and exponential.

The aim of this research is to investigate the influence of electronic commerce on employment rate for a sample including the 27 Member States of the European Union (EU-27), over 2010-2019. The European region hosts e-commerce markets that differ significantly since digital abilities, involving internet use, along with acquiring capacity, are aspects affecting implementation and evolution of e-commerce [6]. Hence, another purpose of our research is to explore the clusters of nations with reference to electronic commerce adoption and employment rate dynamics. For instance, [9] employed hierarchical cluster analysis to examine whether there are substantial variations between European states concerning e-commerce practices, but employment rate was not considered. Hence, our analysis provides fresh evidence in this regard. The loss of jobs in many sectors of the economy in all European Union countries caused by the pandemic in the last two years and concerns in populations to keep or find a job, explains better or justifies our objective to identify and study the factors that influence the employment rate of the population directly. As well, it is frequently claimed that one of the major reasons of regional unemployment gaps is the location of falling or rising activities in specific areas [10]. First, different to the prior literature $[5,11,12]$, this study includes all EU-27 nations. Second, dissimilar to the existing literature that explored the impact of ICT on economic growth [13-21], current quantitative analysis surveys the influence of e-commerce on employment rate. However, we did not find a synthetic measure that assesses the total value of electronic commerce, but we employed three distinct proxies such as the enterprises' total turnover from e-commerce sales, enterprises' turnover from web sales, and enterprises with e-commerce sales of at least $1 \%$ turnover. Therefore, we considered these explanatory variables regarding e-commerce. Moreover, we did not identify any prior research that dealt with the impact of each of the three variables on employment rate. Third, distinct from several studies that explored the impact of ICT on employment [22-24], this research is focused exclusively on e-commerce. Our study is important because it may be a tool for understanding the factors affecting employment rate. It can be beneficial to decision-makers in EU countries and can further influence or stimulate them in order to ensure the economic development, the social and cultural development of communities, and the development of regions and countries.

The rest of this paper is arranged as follows. Section 2 discusses the outcomes of the earlier literature and formulates the research hypotheses. Section 3 presents the quantitative framework. Section 4 exhibits the results. Section 5 concludes this paper and provides 
practical implications for entrepreneurs, as well as political and administrative decisionmakers.

\section{Literature Review and Hypotheses Development}

\subsection{The Impact of ICT on Employment Rate}

Several researchers have studied the extent to which the development of ICT and even e-commerce influences, directly and positively, the research-innovation process in a country. For example, [25] highlights that Europe's digital agenda encourages and stimulates the expansion of ICT, its widespread use, not only at the level of individuals, but also at the level of enterprises, the Internet, e-commerce, and online payment opportunities to enhance research and innovation. Consequently, ICT will lead to a dynamic economy, in which the demand for qualified or highly qualified human capital will increase, and the growing number of people able to work, as well as the increased demand for jobs, will be covered [26]. However, ICT and e-commerce are indivisible as the e-commerce sector is reliant on ICT for its processes and strengthening [27]. For instance, it has been found that the expanding rate of internet users, online expenditure and embracing of innovative technologies are the essential determinants for the expansion of e-commerce in Malaysia [28]. As well, [9] found that e-commerce practices are frequently applied in European nations with more advanced ICT sectors, such as Belgium and Ireland.

Experts from countries outside the EU have also studied the issue of employment rate. For example, the problem of development inequality of some countries (e.g., China) has been analyzed and explained by the decisive influence of employment indicators [29], in Taiwan [30] where the aging of the workforce poses significant problems in employment, and in Nigeria $[31,32]$ where decision-makers must take into account the unemployment and gender inequality in employment. Therefore, [33] claimed that globalization strikes employees not only through salaries, but also by means of engagement. As such, [34] advised that globalization alters employment via expanded commerce, foreign direct investment, and global knowledge relocation.

However, few researchers have verified whether the link is bidirectional or analyzed whether the employment rate depends on the economic development directly. Thus, [35] makes an analysis for Romania and finds that an increased level of employment determines a substantial economic development through a high work performance, but on the other hand, the level of economic development influences it, by diversifying the production and services sector. An equally complex analysis of the relationship between sustainable development and employment by sector of activity for the EU countries was conducted by [36]. The analyses reveal inconclusive, even contradictory, results, given that a GDP growth is based, in contemporary society, on technological progress and automation, which could lead to the replacement of the workforce represented by human capital and therefore, in the short term, could lead to an employment rate decrease. However, a sustained development will lead to a consistent increase in production and services, which will require more jobs, thereby an increase of the employment rate.

Similarly, by analyzing the relationship between employment rate, unemployment, and economic development, [37] shows that an increase in job demand is not always the consequence of economic development or the creation of new jobs, because it could be the result of population growth, just as a higher unemployment rate does not necessarily mean lower economic development. Therefore, researchers need to expand their research on the dependence of the population employment rate on economic development and focus on identifying indicators the decision-makers can use to enhance employment at regional, territorial, national, or sectoral levels.

ICT includes, by its definition, several fields: communication technologies, software products and tools, information technologies, artificial intelligence, computational infrastructure, cloud technologies, design, creation, and development of information systems.

Several studies have analyzed the influence of some of these components on the economic development of a country or region [18]. Researchers have analyzed the influence 
of ICT on the economic development in EU countries [13-15,38] or outside the EU, in countries such as India [39], China [17], and Australia [18]. Reference [19] focuses on the impact of ICT on GDP per capita in 18 Arab countries, during the years 1995-2013. It shows that ICT has a positive impact on the economic growth of certain Arab countries, along with other factors such as population growth and training of human capital development, by excluding inflation, because it had a negative impact on the economic growth in the analyzed countries. In addition, the effects of ICT on society, its role in shaping the knowledge-based society and knowledge transfer are addressed by many researchers who have explored the role of ICT in the economic development of highly developed or developing countries and often present contradictory results.

Investigating the economies of the OPEC Member Countries in 1990-2007, [20] identified a direct influence of ICT investments on the economic development, for instance in Mexico the impact of investments in mobile phones, computers, Internet, and fiber optics on GDP was significant. Reference [21] demonstrates the importance of exploring the regional development in Indonesia where investments in ICT and especially in mobile telephony stimulated the economic development of 34 different provinces. Similarly, [26] shows that investments in ICT represent a sustainable development solution for emerging countries because they generated GDP growth, productivity, and labor efficiency, and improved the quality of production and trade services, accessibility of all information, communication networks, education, and innovation. This can be successfully achieved only in combination with investments in organizational and human capital [40]. Moreover, the authors highlight that ICT creates jobs. However, for the case of the US, [22] found that information technology can be both upskilling and deskilling.

In this regard, [24] analyzed data from the EU-27 countries and demonstrated that the development of ICT and commerce leads to a direct increase of employment. Reference [23] documented the case of the Organization of Islamic Conference (OIC) nations where, for each $1 \%$ rise in ICT expenses, employment rate grows by $0.045 \%$. Additionally, [41] identified a direct positive relationship between the use of ICT applications and employment, with a major impact on company-level ICT applications such as web pages.

Therefore, most research focuses on the direct impact of ICT investments, sometimes on their components and the economic development, without analyzing whether this influence is also on employment, whether it influences the employment rate in one way or another. This issue needs further investigation from this perspective to understand how decision-makers react under these circumstances since there is a large population that has lost jobs in the last two years and, on the other hand, digitalization, expansion of ICT, as part of the general policy of the EU, might scare many of them.

Along with the development of ICT infrastructure, the unprecedented development of the Internet in recent years, Internet access and communication, communication networks and Web programming have accelerated the development of platforms for promoting and selling products online, online payments, online contracting and electronic signature, direct communication, and service-oriented programming. Thus, e-commerce appeared, developed, and is being perfected continuously, which has allowed companies to carry out commercial transactions at the international level, also raising a series of new problems: security of transactions and reduction of fraudulent activities, increased customer comfort, a new way of thinking about marketing, and logistics for the product supplier [42]. Ecommerce continues to grow rapidly, having very large economic and social impacts. Yet few researchers have tried to measure the impact of the development of e-commerce on employment rate.

\subsection{The Influence of E-Commerce on Employment Rate}

Although e-business can simultaneously stimulate and reduce employment rate in many professions and industries, [43] demonstrates that it certainly stimulates employment in the industries of hardware, software, communications equipment, e-business infrastructure and technology, cloud computing, and IoT. Likewise, it accelerates employment in 
other fields of activity related to networks and Web, such as production, design, maintenance services, procurement, promotion, marketing, communication, sales management, deliveries, management, consulting, and data operations. Thus, it improves the customer's comfort, who buys a product more easily and conveniently, communicates better with the seller, makes product evaluations or complaints, and benefits from post-warranty maintenance services. E-commerce creates new jobs directly, in the field of information and communication technologies, but also indirectly through an extremely dynamic increase of the volume and diversity of product demand [44]. As a direct consequence of the changing way of doing business in the digital society, e-commerce has also led to a slight reduction of jobs in reformed fields or in disappearing manufacturing technologies, such as retail, post offices, and tour operators. Unskilled or low-skilled workers, those made redundant or aspiring to better paid jobs, must constantly develop IT skills [45] for employment in the fields of production, research, design, and services in ICT.

However, customer comfort also involves ensuring direct, fast, online payment methods. Companies have considered these and have developed diversified and better-secured online payment methods $[46,47]$. This is how new business models have appeared, and new processing methods, especially when the multitude of data collected about customers has become an advantage for the owner of the e-commerce platform. Hence, this has generated many new jobs.

The studies $[44,48]$ prove the direct positive impact of e-commerce on the labor workforce occupation indicators, as well as on the total number of Internet users. This will force, for a short time, closing some shops that in turn will lead in the short term to the loss of some jobs in sales $[44,49,50]$ as well as to a large number of employments in those support sectors for online shops (IT\&C, cargo transport and deliveries, sales analysis, design, communication, different types of operators, and so on) [51,52].

Traditional companies can benefit from e-commerce advantages through lowered costs for processing, storage, and distribution of information [51], in order to provide better customer support for product accesibility and availability, to prepare its staff and the marketing mix and payment strategies [53].

The study also presents the impact of e-commerce for local communities, through its direct impact on labor force occupation, local budget revenues, as well as the possibility to gain loyalty from customers through correct, complete, and fast information provided to them. The studies $[43,54]$ analyzed ICT fields and sectors that would be very positively influenced by growth of e-commerce, that would have direct impact on increased labor force occupation and would be specialised in: maintenance, hardware support, software development, web design and programming, database and network administrators, computer operators and connected fields of expertise, sales workers, business managers, negotiators, and so on. According to $[54,55]$, most of the companies that are easily adaptable developing e-commerce and stimulating employment growth in this sector are the small and medium enterprises. The labour force analysis [56] for the retail industry in 35 European countries over a 10-year timeframe (2007-2016) shows the negative influence of the total revenue of e-commerce companies on labour force occupation for the retail commerce sector. Together with the strong development of e-commerce, with its acceptance by customers and suppliers, the sales volume and the number of available jobs have increased after 2016 and that has determined its direct impact on jobs growth $[55,56]$.

Online commerce could not develop without increasing customer loyalty in the providers of such platforms. Thanks to the evolution of e-commerce and the widespread use of social media platforms, social commerce (s-commerce) has emerged and it has considerably influenced the buying behavior of purchasers [57,58]. Thus, [59] estimates that buying behavior is significantly influenced by customer reviews (71\%). Ref. [60] shows that, in addition to the aesthetics of the sales platform and the ease of use, loyalty is important for customers who choose a particular online store and remain loyal to it. The members of virtual communities, who inform shoppers about various aspects of the online shopping process, do not know one another, because they are connected through 
information technologies. However, they can influence the online buying process, they can encourage or not a buyer to choose a certain online store, or to remain loyal to it or not. The behavior of the supplier of products or services, the quality and price of the products, and the transport conditions, are also considered.

The online providers, interested in the degree of customer satisfaction for the products and services offered, have found solutions for text analysis through which they answer a series of well thought out and targeted questions [61]. There are methods of extracting and processing texts, followed by vectorization of the numbers associated with the letters in the texts and their numerical processing. Hence, it is possible to create customer communities for online sales platforms, which customize the offer of products or services for each consumer, through better-targeted marketing and communication activity [62].

Following this effective communication between customers and online service providers, [63] analyzes the positive impact of e-commerce development on social activities, its implications on the social development of communities through services provided in health, education, art, culture, research, relaxation and movement, transportation, agricultural services, information, sales of products, and services in all fields. Besides these, through the offer of online sales platforms, the rental of electronic textbooks is also available to meet the increasingly diverse requirements of specialists from different cultural, academic, or research backgrounds. Reference [64] studies not only the factors that influence the prices of these extremely useful digital textbooks, but also the possible depreciation of the value of their content over time, in some areas.

Lately, a new form of e-commerce, called m-commerce, which defines online transactions using mobile devices, has developed tremendously. To show its importance and its special evolution, [65] presents surprising figures. Globally, in 2020, the value of mobile commerce was USD 2.91 trillion, and its share of the global e-commerce has increased by $52.4 \%$ since 2016 , reaching $70.4 \%$ [66], while in 2021, it is estimated that it will increase by $72.9 \%$ [67] of the global e-commerce and will reach the value of USD 5 trillion [68]. More and more people are now using mobile devices (phones, tablets) to search and find out information about products, and to purchase and complete transactions by paying online. Reference [65] analyzes the increasing use of mobile devices by young people (generation $Z$ ) and finds that in Romania, especially in rural areas and disadvantaged groups, many users do not have the knowledge and skills to use mobile devices connected to the Internet. This shows once again that the Internet, e-commerce, and the hardware and software infrastructure of ICT lead to development and economic growth, but they also require knowledge and expertise, either to use the services and facilities offered, or to contribute to the installation, maintenance, design, and development of the software required for all computer networks that allow global communication.

Ref. [69] claimed that e-commerce exhibits several benefits such as strategic, informational, and operational. In this regard, [70] claimed that vendors in Europe generated 1.3 million net direct jobs among 2008-2018, of which 300,000 were in e-commerce. Reference [11] explored seven European nations over 2007-2010 and found that enhanced use of ICT within companies does not lessen the numbers of workers they hire. As well, [12] analyzed 14 European countries during 2002-2010 and proved that a rise in e-sales will boost the rate of labor productivity by 0.3 percentage points over a two-year period.

The study [48] shows e-commerce impact on explosive sales growth for products and services, on the volume of international commerce [71], including regarding GDP growth. E-commerce does not care for borders, and through its flexible and easily adaptable structure, it quickly attracts the classical commerce in the virtual environment. Continuous growth of e-commerce generates constant sales growth [72], that consequently generates demand increase and, as an immediate result, the growth of production, income, and national GDP. 


\subsection{Economic Development-Research and Development-Employment Rate Nexus}

Numerous studies have analyzed the link between economic development, measured by the GDP per capita and the employment rate in the EU countries, and have shown that economic development depends on the employment rate [73-75] in a different way, according to the level of development of a country. In one study [74], the analyzed countries were grouped in two clusters: one for developed countries, the other for less developed countries. Along GDP as an indicator of economic growth, the remittances indicator (returned money in origin country by citizens working abroad) was used as well. The study showed that remittances have a contrary effect, as the following: in less developed countries, remittances tend to support family household expenditures, negatively influencing job occupation rate; in developed countries, remittances are used for investments, positively influencing job occupation rate.

It also identified the relationship between sustainable economic development, which is necessary and mandatory for all countries, and employment [36]. The sectoral approach of employment is based on the sectoral analysis of sustainable development at regional and territorial levels, in the economic, social, and environmental fields [76]. Moreover, the analysis of the impact of employment on the economic development of EU countries is extended by analyzing the spatial effects of employment [77], showing that regional sustainable development depends on the performance of the neighboring regions and highlighting that spatial influences are crucial in sustainable development policies and the issue of employment.

However, few researchers address in their studies the relationship between investment in research and development (R\&D) and employment, but they demonstrate that R\&D influences directly the economic development, labor productivity, and wage levels in EU countries [78]. Studying several developing countries, [79] argues that the workplace and the economic growth based on natural resources are gone and that the present must be oriented on the development of a modern research and development (R\&D) infrastructure. This infrastructure needs to rely on a modern communications network, correct, complete, and efficient use of the information available to decision-makers, offer benefits to ensure the competitiveness and sustainability of organizations, society, environment, and human resources. Likewise, researchers have analyzed the impact of research and development on economic growth in Singapore [80] and Slovenia [81], showing that the economic development leads to an increase in the volume of production and services, which also contributes to the creation of new jobs.

Studying the impact of public investments on R\&D and economic development in general, the development of companies that benefited from these investments or the employment of the population (in the field of $R \& D$ and non-R\&D), [82] differentiates between the global impact of employment and internal employment within companies. The study measures whether public funding of R\&D has an impact on employment. Starting from the conclusion of previous studies, that public funding of R\&D does not exclude private funding of R\&D. The author analyzes in Finnish companies the impact that the public investments in R\&D have on the employment of internal and global non-R\&D population. Knowing that in the short term, process innovation can lead to the loss of jobs, the author demonstrates that increasing the competitiveness of the company can stimulate the growth of production and, implicitly, the offer of jobs. Moreover, the author demonstrates that public funding of R\&D stimulated private companies to innovate, which added private funding to public spending. The results show that this process of adding private funding is stronger in large companies, which have greater financial power. The study shows that the global impact of R\&D on employment differs from the domestic one as the latter depends on the period of economic growth or recession of the economy of countries. The impact of R\&D development is positive on R\&D employment. However, the results of the research show that although public funding of R\&D does not have a statistically significant effect on non-R\&D employment, it has a slightly positive impact on employment in all areas. 
Continuing this analysis and studying the value of tax incentives and subsidies granted by the French public authorities to finance the R\&D activities of SMEs and very small enterprises, in 2003-2010, [83] shows that their impact on employment in research and development was positive and strong. This is how France became, in 2013, one of the largest R\&D financiers in the world. Ref. [84] studied 3300 Korean firms and identified a positive impact of funding on the employment in the field of research and innovation.

Ref. [85] deals with the impact of government subsidies for R\&D employment on 25 OECD countries, in 1983-2006, both in the short term and long term. Considering several government support measures for R\&D activities, including financial support, the study demonstrates that government subsidies for $R \& D$ had a positive effect on $R \& D$ employment. Ref. [86] estimates the impact of research and development on employment levels in the UK labor market in 2001-2011. Noticing that R\&D activities can primarily change the structure and level of education of the population employed in $R \& D$, the authors conclude that an increase in R\&D, by enhancing production, can directly influence the demand for jobs in R\&D. Then, as a multiplier effect, the demand for specialists in various professions and unskilled workers in various activities increases. The development of R\&D can have contradictory effects: through innovation, it can lead to the disappearance of jobs, which can cause unemployment, but it can also create opportunities, even incentives, to make employees establish their own independent activities. The influence of R\&D is different for the employed population and the self-employed, depending on age.

Studies have mostly shown that R\&D drives job opportunities in high-tech sectors and in sectors that implement ICT, and tends to have a slightly positive impact on employment locally and even nationally. Our analysis reveals that few studies have analyzed the impact of e-commerce, the expansion of digitalization, and the funding of R\&D activity on employment, and these studies present contradictory results.

In line with the prior literature, the following research hypotheses are formulated:

Hypothesis 1 (H1). The value of e-commerce sales positively influences employment rate.

Hypothesis 2 (H2). Web sales positively influence employment rate.

Hypothesis 3 (H3). The share of enterprises with e-commerce sales positively influences employment rate.

\section{Research Design}

\subsection{Database and Variables}

In the current research, the data were acquired from the Eurostat database. Table 1 exhibits the employed variables, along with their definitions. The data used for quantitative investigation encompass the period from 2010-2019 and the 27 European Union (EU) nations. The time frame was chosen corresponding to the accessibility of the entire data series. The benefits of using panel data consists of more precise inference of model parameters, better capability for catching the complexity of explored phenomena than a single cross section or time series data, along with facilitating calculation and statistical deduction $[87,88]$. However, panel data are not free of limitations, showing issues regarding design and data collection, biases of measurement errors, as well as selectivity challenges [88,89].

The enclosed EU states are Belgium (BE), Bulgaria (BG), Czechia (CZ), Denmark (DK), Germany (DE), Estonia (EE), Ireland (IE), Greece (EL), Spain (ES), France (FR), Croatia (HR), Italy (IT), Cyprus (CY), Latvia (LV), Lithuania (LT), Luxembourg (LU), Hungary (HU), Malta (MT), Netherlands (NL), Austria (AT), Poland (PL), Portugal (PT), Romania (RO), Slovenia (SI), Slovakia (SK), Finland (FI), and Sweden (SE). The main types of measures employed for this econometric examination include employment rate, e-commerce, and country-level control variables. All the utilized variables are expressed as ratios. 
Table 1. Variable presentation.

\begin{tabular}{|c|c|c|c|c|c|}
\hline Variables & Explanation & Meaning & Measurement & Data Source & Time Span \\
\hline \multicolumn{6}{|c|}{ Dependent Variables Concerning Employment Rate } \\
\hline EMPL & $\begin{array}{l}\text { National employment rate by sex, } \\
\text { age group 20-64-Total }\end{array}$ & $\begin{array}{l}\text { The employment rate is calculated by dividing the } \\
\text { number of persons aged 20-64 in } \\
\text { employment by the total population of the same age } \\
\text { group. The indicator is based on the EU Labour Force } \\
\text { Survey }\end{array}$ & $\begin{array}{l}\text { Percentage of total } \\
\text { population }\end{array}$ & Eurostat [T2020_10] & 1993-2019 \\
\hline \multicolumn{6}{|c|}{ Explanatory Variables Concerning E-Commerce } \\
\hline VECS & $\begin{array}{c}\text { Value of } \\
\text { e-commerce sales }\end{array}$ & $\begin{array}{c}\text { Enterprises' total turnover from e-commerce sales-All } \\
\text { enterprises, without financial sector (10 persons } \\
\text { employed or more) }\end{array}$ & Percentage of turnover & $\begin{array}{c}\text { Eurostat } \\
\text { [ISOC_EC_EVALN2] }\end{array}$ & $2010-2020$ \\
\hline WS & Web sales & $\begin{array}{l}\text { Enterprises' turnover from web sales-All enterprises, } \\
\text { without financial sector ( } 10 \text { persons employed or more) }\end{array}$ & Percentage of turnover & $\begin{array}{c}\text { Eurostat } \\
\text { [ISOC_EC_EVALN2] }\end{array}$ & 2009-2020 \\
\hline ECS & E-commerce sales & $\begin{array}{l}\text { Enterprises with e-commerce sales of at least } 1 \% \\
\text { turnover-All enterprises, without financial sector (10 } \\
\text { persons employed or more) }\end{array}$ & Percentage of enterprises & $\begin{array}{c}\text { Eurostat } \\
\text { [ISOC_EC_ESELN2] }\end{array}$ & 2009-2020 \\
\hline \multicolumn{6}{|c|}{ Country-Level Control Variables } \\
\hline $\mathrm{RD}$ & $\begin{array}{l}\text { Research and } \\
\text { development } \\
\text { expenditure-Business } \\
\text { enterprise sector }\end{array}$ & $\begin{array}{c}\text { R\&D expenditures include all expenditures for R\&D } \\
\text { performed within the business enterprise sector (BERD) } \\
\text { on the national territory during a given period, } \\
\text { regardless of the source of funds }\end{array}$ & $\begin{array}{l}\text { Percentage of GDP (R\&D } \\
\text { intensity) }\end{array}$ & Eurostat [TSC00001] & 2008-2019 \\
\hline EICT & Employed ICT specialists—-total & Employment of ICT specialists & $\begin{array}{l}\text { Percentage of total } \\
\text { employment }\end{array}$ & $\begin{array}{c}\text { Eurostat } \\
\text { [ISOC_SKS_ITSPT] }\end{array}$ & $2004-2020$ \\
\hline IA & Internet access & Enterprises with Internet access & Percentage of enterprises & $\begin{array}{l}\text { Eurostat } \\
\text { [ISOC_CI_IN_EN2] }\end{array}$ & 2009-2020 \\
\hline
\end{tabular}




\subsection{Econometric Framework}

Primarily, so as to investigate electronic commerce adoption and employment rate dynamics in the $27 \mathrm{EU}$ countries, the cluster analysis is implemented, similar to [47], namely the k-means method as in [62]. The aim of the clustering approach is to split a dataset into several classes so that the similarity within a class is larger than among the classes [90]. Like [91], we considered $X=\left\{x_{i}\right\}, i=1, \ldots, 27$, a set of $27 \mathrm{~d}$-dimensional points to be clustered into a set of $K$ clusters, $C=\left\{c_{k}, k=1, \ldots, K\right\}$ and $\mu_{k}$ the mean of cluster $c_{k}$. The squared error among $\mu_{k}$ and the points in cluster $c_{k}$ is described as below:

$$
J\left(c_{k}\right)=\sum_{x_{i} \in c_{k}}\left\|x_{i}-\mu_{k}\right\|^{2}
$$

Specifically, the k-means unsupervised learning algorithm resolves the challenge of clustering by minimizing the sum of squared errors [92] over all $K$ clusters:

$$
J(C)=\sum_{k=1}^{K} \sum_{x_{i} \in c_{k}}\left\|x_{i}-\mu_{k}\right\|^{2}
$$

Further, in order to explore the influence of electronic commerce on employment rate, the subsequent baseline empirical model is specified as the following:

$$
y_{i t}=f\left(E C_{i t}, C C_{i t}\right)
$$

where $y$ refers to the employment rate, $E C$ denotes the variables relating to e-commerce, and $C C$ represents the country-level control variables.

In line with [11], the general form of panel data fixed-effects regression models is expressed in Equations (4)-(6):

$$
\begin{gathered}
E M P L_{i t}=\delta_{i}+\beta_{1} V E C S_{i t}+\beta_{2} G R_{i t}+\beta_{3} R D_{i t}+\beta_{4} E I C T_{i t}+\beta_{5} I A_{i t}+u_{i t} \\
E M P L_{i t}=\delta_{i}+\beta_{1} W S_{i t}+\beta_{2} G R_{i t}+\beta_{3} R D_{i t}+\beta_{4} E I C T_{i t}+\beta_{5} I A_{i t}+u_{i t} \\
E M P L_{i t}=\delta_{i}+\beta_{1} E C S_{i t}+\beta_{2} G R_{i t}+\beta_{3} R D_{i t}+\beta_{4} E I C T_{i t}+\beta_{5} I A_{i t}+u_{i t}
\end{gathered}
$$

where $i=1, \ldots, 27$ depicts the EU member nations, $t=2010, \ldots, 2019$ exhibits the years over the period explored. $\beta_{1}, \beta_{2}, \beta_{3}, \beta_{4}, \beta_{5}$ are the coefficients of the explanatory variables. The term $\delta_{i}$ in Equations (4)-(6) denotes the constant parameter that differs across nations, but not over time. Each particular constant controls for country-specific disparities, although the error terms $\left(u_{i t}\right)$ are expected to be independent, with the mean null and constant variance for all involved nations and through the time spans.

As well, the standard specification of panel data random-effects regression models is shown in Equations (7)-(9):

$$
\begin{gathered}
E M P L_{i t}=\delta_{i}+\beta_{1} V E C S_{i t}+\beta_{2} G R_{i t}+\beta_{3} R D_{i t}+\beta_{4} E I C T_{i t}+\beta_{5} I A_{i t}+\omega_{i}+\psi_{i t} \\
E M P L_{i t}=\delta_{i}+\beta_{1} W S_{i t}+\beta_{2} G R_{i t}+\beta_{3} R D_{i t}+\beta_{4} E I C T_{i t}+\beta_{5} I A_{i t}+\omega_{i}+\psi_{i t} \\
E M P L_{i t}=\delta_{i}+\beta_{1} E C S_{i t}+\beta_{2} G R_{i t}+\beta_{3} R D_{i t}+\beta_{4} E I C T_{i t}+\beta_{5} I A_{i t}+\omega_{i}+\psi_{i t}
\end{gathered}
$$

where $\omega_{i}$ is the country-specific random effects that fluctuate throughout nations, being expected to be random and not correlated with the independent measures. The $\psi_{i t}$ term is the country-specific error. For the purpose of establishing whether fixed-effects or randomeffect estimators are appropriate for estimation, the test of Hausman [93] is implemented, similar to $[19,20]$. If the associated $p$-value Prob $>$ chi2 is larger than 0.05 , then the randomeffect estimator is suitable, otherwise the fixed-effect estimator should be applied.

Furthermore, in order to examine the persistence of the empirical outcomes to different econometric specifications, the method of moments quantile regression models (MM-QR) with fixed effects as proposed by [94] is applied. The quantile regression method offers summary statistics on both the central part and the tails of the distribution of the dependent 
variable, allowing for a more thorough examination of the effect of certain explanatory variables. Even if a quantile regression is robust to outliers, it does not consider potential ignored heterogeneity throughout entities inside a panel. However, the MM-QR technique can detect the conditional heterogeneous covariance effects of the drivers of EMPL by allowing the specific effects to influence the whole distribution rather than just changing means as in earlier approaches $[95,96]$. The general form of the regression model is depicted below:

$$
Q_{Y}\left(\tau \mid X_{i t}\right)=\left(\alpha_{i}+\delta_{i} q(\tau)\right)+X_{i t}^{\prime} \beta+Z_{i t}^{\prime} \gamma q(\tau)
$$

where $X_{i t}^{\prime}$ is a vector of independent variables, $Q_{Y}\left(\tau \mid X_{i t}\right)$ signifies the quantile distribution of the dependent variable which is conditional on the location of independent measure, $\alpha_{i}(\tau)=\alpha_{i}+\delta_{i} q(\tau)$ is the scalar coefficient which is representative for the quantile $\tau$ fixed effect for country $i . q(\tau)$ refer to the $\tau$-th sample quantile which is computed by resolving the subsequent optimization problem:

$$
\min _{q} \sum_{i} \sum_{t} \rho_{\tau}\left(R_{i t}-\left(\delta_{i}+Z_{i t}^{\prime} \gamma\right) q\right)
$$

where $\rho_{\tau}(\mathrm{A})=(\tau-1) \mathrm{AI}\{\mathrm{A} \leq 0\}+\tau \mathrm{AI}\{\mathrm{A}>0\}$ is the check-function.

\section{Econometric Outcomes}

\subsection{Summary Statistics, Correlations, and Cluster Analysis}

Summary statistics of the employed indicators are exhibited in Table 2, whereas Figure 1 provides the mean values of the variables regarding employment rate and ecommerce. Further, Appendix A shows the evolution of employment rate and e-commerce measures for each covered country.

Table 2. Descriptive statistics.

\begin{tabular}{ccccccc}
\hline Variables & Mean & Median & Maximum & Minimum & Std. Dev. & Observations \\
\hline EMPL & 70.34245 & 70.8 & 82.4 & 52.9 & 6.02314 & 351 \\
VECS & 14.83212 & 14 & 44 & 1 & 7.551115 & 274 \\
WS & 5.218107 & 5 & 20 & 1 & 2.983038 & 243 \\
ECS & 16.18027 & 16 & 38 & 3 & 7.248266 & 294 \\
GR & 0.774074 & 1.4 & 24 & -14.3 & 4.021252 & 324 \\
RD & 0.958333 & 0.71 & 2.67 & 0.07 & 0.690414 & 324 \\
EICT & 3.72792 & 3.6 & 7.6 & 1.5 & 1.223375 & 351 \\
IA & 96 & 97 & 100 & 79 & 4.191512 & 270 \\
\hline
\end{tabular}

Source: Authors' calculations. Notes: For the description of measures, please see Table 1.

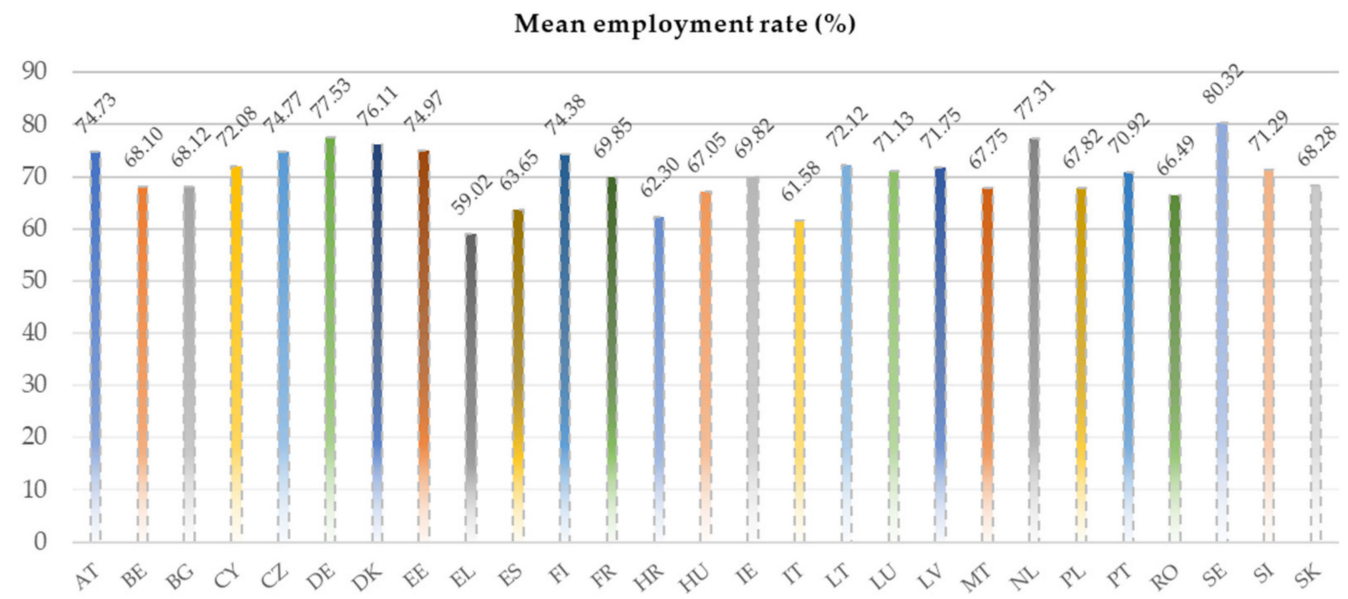

(a)

Figure 1. Cont. 
Mean enterprises' total turnover from e-commerce sales (\%)

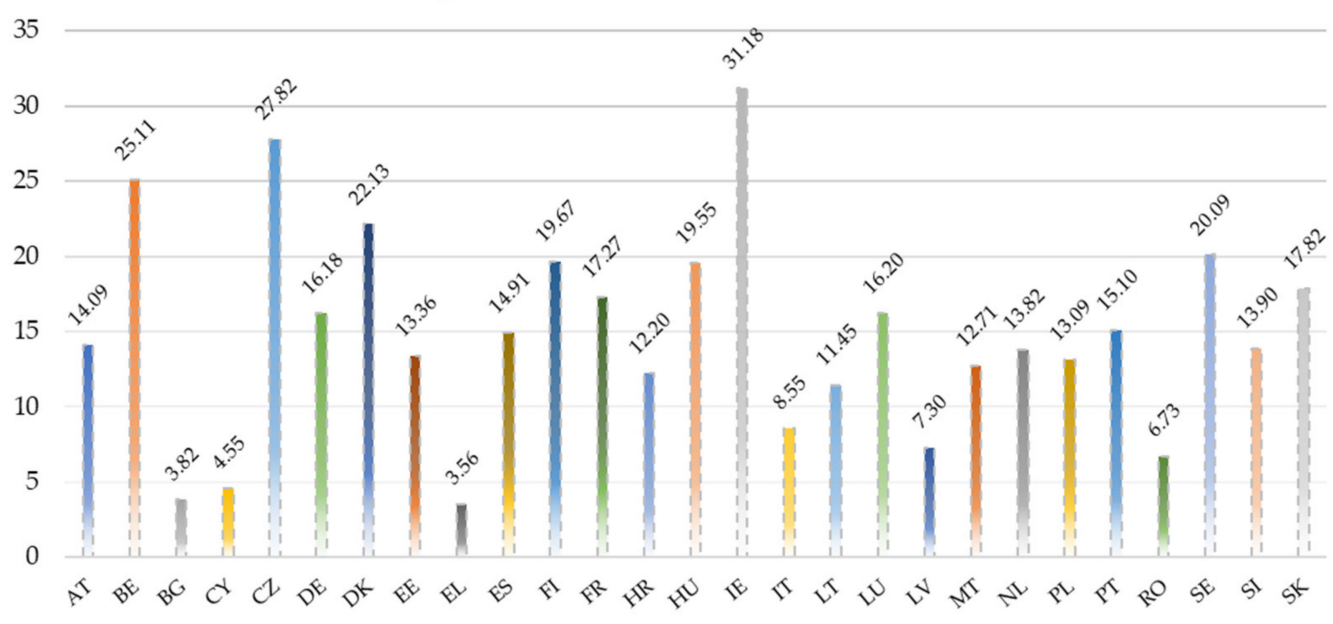

(b)

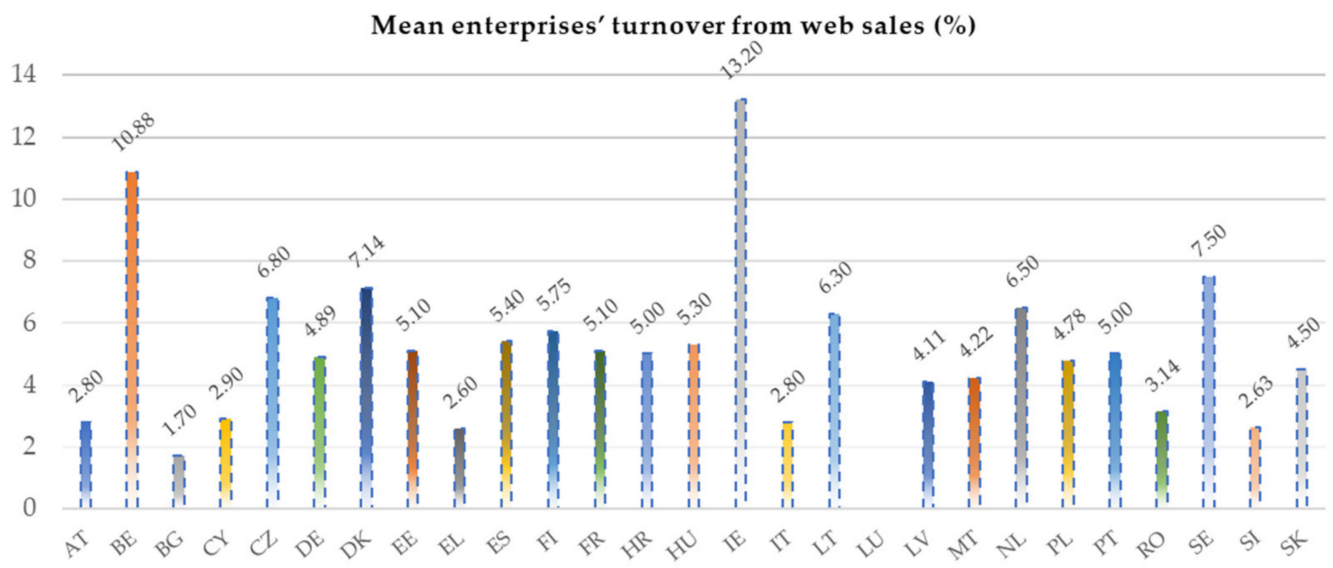

(c)

Mean percentage of enterprises with e-commerce sales of at least $1 \%$ turnover (\%)

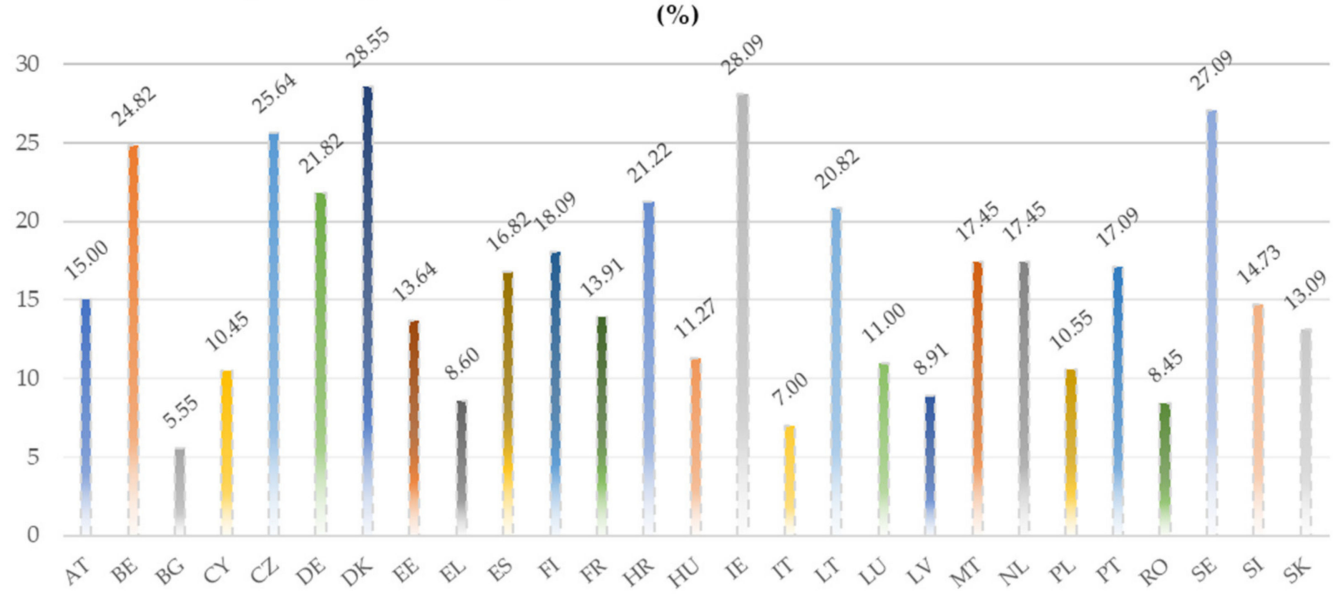

(d)

Figure 1. The annual means of (a) employment rate, (b) enterprises' total turnover from e-commerce sales, (c) enterprises' turnover from web sales, and (d) percentage of enterprises with e-commerce sales of at least $1 \%$ turnover. Source: Authors' work. 
As compared to the European pillar of social rights action plan [16] that agreed no less than $78 \%$ of the population aged 20-64 should be in employment by 2030 , the mean value of EMPL is below the proposed target. However, there are nations such as Czechia, Denmark, Germany, Estonia, Lithuania, The Netherlands, and Sweden which have already exceeded the proposed target for 2030. Due to the COVID-19 pandemic, the employment rate decreased in all explored nations (see Figure A1). With reference to the mean value of e-commerce sales, $14.83 \%$ of the 27 member states of the European Union enterprises total turnover derives from e-commerce sales. Nevertheless, there are nations like Ireland where over 30\% of total turnover stems from e-commerce sales, but also countries such as Bulgaria, Cyprus, or Greece showing a mean value of VECS below 5\%.

The mean enterprises' turnover from web sales is much lower, namely $5.22 \%$, but Ireland reaches the highest mean value (13.20\%). In addition, the mean value of enterprises with e-commerce sales of at least $1 \%$ turnover is $16.18 \%$, the highest mean values being registered in Denmark (28.55\%), Ireland $(28.09 \%)$, and Sweden $(27.09 \%)$. Though the coronavirus pandemic slowed the employment rate, it increased electronic commerce in most of the investigated countries (see Figures A2-A4). The closure of brick-and-mortar stores had a positive effect on electronic transactions [97] since the e-commerce sector supported individuals in nations with even the harshest quarantine arrangements to get access to commodities [98]. According to [70], the COVID-19 pandemic boosted the rise of online retail from 2019-2020 to three times that from 2018-2019.

The correlations among selected measures are reported in Table 3 and are also plotted in Figure 2. Accordingly, except the correlations among e-commerce related variables, strong associations among the rest of the explanatory variables are not registered. Therefore, the measures regarding e-commerce will be included in distinct regression equations to avoid the multicollinearity issue.

Table 3. Pearson correlation matrix.

\begin{tabular}{|c|c|c|c|c|c|c|c|c|}
\hline Variables & EMPL & VECS & WS & ECS & GR & RD & EICT & IA \\
\hline \multirow[t]{3}{*}{ EMPL } & 1 & & & & & & & \\
\hline & - & & & & & & & \\
\hline & - & & & & & & & \\
\hline \multirow[t]{3}{*}{ VECS } & 0.398005 & 1 & & & & & & \\
\hline & (6.287053) & - & & & & & & \\
\hline & {$[0.0000]$} & - & & & & & & \\
\hline \multirow[t]{3}{*}{ WS } & 0.356558 & 0.813687 & 1 & & & & & \\
\hline & (5.53052) & (20.28452) & - & & & & & \\
\hline & {$[0.0000]$} & {$[0.0000]$} & - & & & & & \\
\hline \multirow[t]{3}{*}{ ECS } & 0.524945 & 0.781687 & 0.756347 & 1 & & & & \\
\hline & (8.937666) & (18.16296) & (16.75482) & - & & & & \\
\hline & {$[0.0000]$} & {$[0.0000]$} & {$[0.0000]$} & - & & & & \\
\hline \multirow[t]{3}{*}{ GR } & 0.152729 & 0.184509 & 0.279891 & 0.146268 & 1 & & & \\
\hline & (2.239529) & (2.720498) & $(4.224864)$ & (2.142672) & - & & & \\
\hline & {$[0.0262]$} & {$[0.0071]$} & {$[0.0000]$} & {$[0.0333]$} & - & & & \\
\hline \multirow[t]{3}{*}{$\mathrm{RD}$} & 0.527984 & 0.471281 & 0.27195 & 0.508993 & -0.21782 & 1 & & \\
\hline & (9.009323) & (7.743349) & (4.095273) & (8.569083) & $(-3.23419)$ & - & & \\
\hline & {$[0.0000]$} & {$[0.0000]$} & {$[0.0001]$} & {$[0.0000]$} & {$[0.0014]$} & - & & \\
\hline \multirow[t]{3}{*}{ EICT } & 0.605317 & 0.582777 & 0.528088 & 0.605512 & -0.04471 & 0.726171 & 1 & \\
\hline & (11.02015) & (10.39245) & (9.011805) & (11.02576) & $(-0.64856)$ & (15.30617) & - & \\
\hline & {$[0.0000]$} & {$[0.0000]$} & {$[0.0000]$} & {$[0.0000]$} & {$[0.5173]$} & {$[0.0000]$} & - & \\
\hline \multirow[t]{3}{*}{ IA } & 0.540838 & 0.426835 & 0.343014 & 0.519296 & -0.06713 & 0.486355 & 0.530324 & 1 \\
\hline & (9.317852) & (6.839796) & (5.291802) & (8.805707) & $(-0.975)$ & (8.066216) & (9.064836) & - \\
\hline & {$[0.0000]$} & {$[0.0000]$} & {$[0.0000]$} & {$[0.0000]$} & [0.3307] & {$[0.0000]$} & {$[0.0000]$} & - \\
\hline
\end{tabular}

Source: Authors' calculations. Notes: Statistics in ( ) exhibit t-statistic. Figures in [] shows Probability $|\mathrm{t}|=0$ For the description of measures, please see Table 1. 


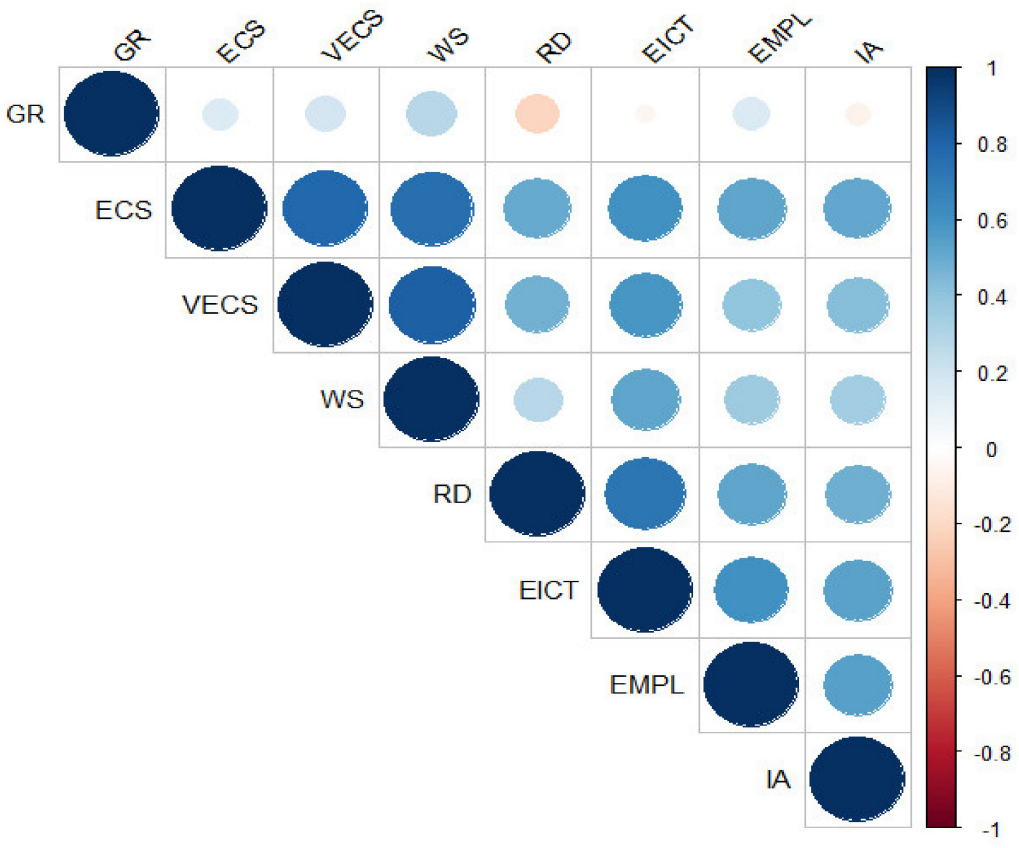

Figure 2. Correlation matrix plot. Source: Authors' work. Notes: For the description of measures, please see Table 1 .

Further, the cluster plots for 2010, 2015, 2017, and 2019 are exhibited in Figure 3. To determine the optimal number of clusters, the silhouette method is considered. Accordingly, two clusters are advised, except 2019 (see Appendix B).

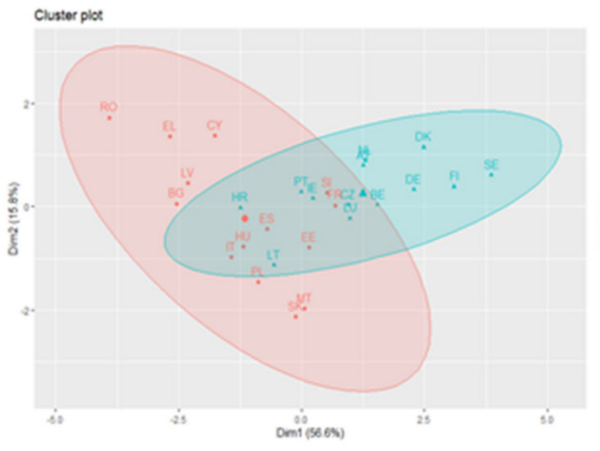

(a)

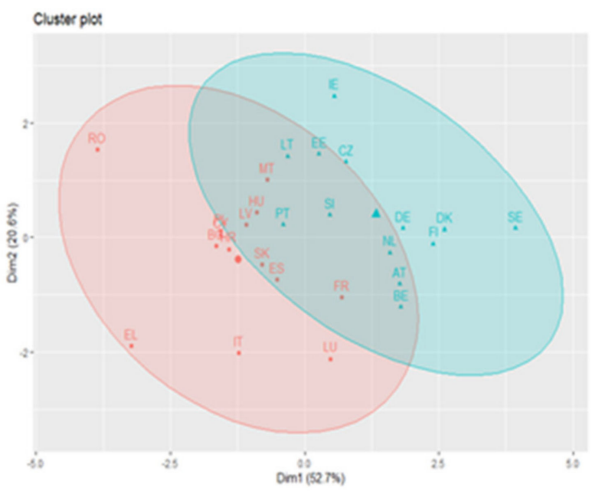

(c)

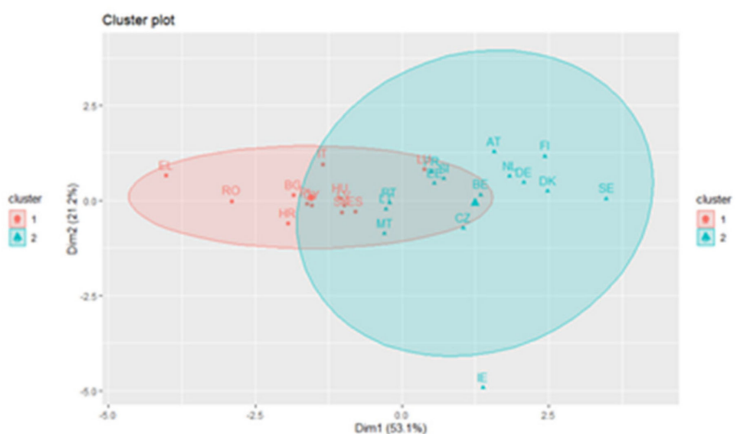

(b)

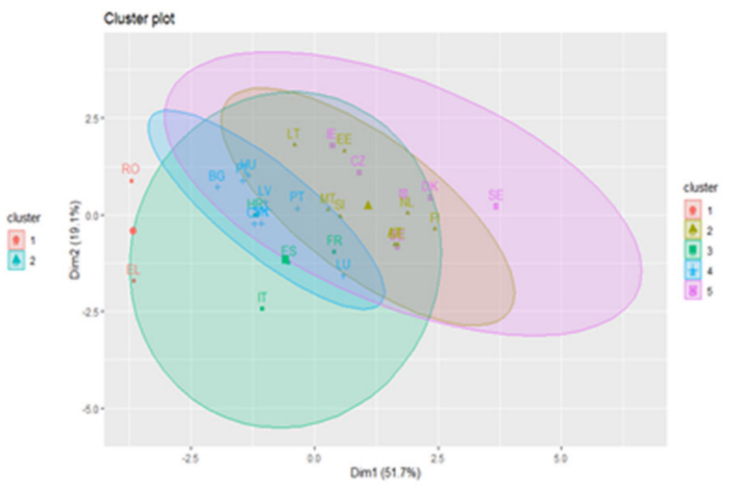

(d)

Figure 3. Cluster plots for (a) 2010, (b) 2015, (c) 2017, (d) 2019. Source: Authors' work. 
Therefore, generally, Western Europe reveals the most developed e-commerce marketplace in EU-27, the nations with the highest adoption and employment rate being Ireland, Denmark, and Sweden, whereas the lowest figures are registered in the Eastern part of Europe, in Romania and Bulgaria. The outcomes are explained by the fact that Internet accessibility is common in Western Europe, being the essential element that fosters e-commerce expansion, also linked with the high penetration rate of digital tools [99]. Consequently, numerous brick-and-mortar retailers were able to quickly turn to e-commerce [100]. For instance, Ireland was one of the first EU member states to apply the Electronic Signatures Directive, as well as the Electronic Commerce Directive [101]. Furthermore, Irish residents spend a considerably greater amount of money online every year than most other European nations [102]. Denmark registers a proper physical, digital, and banking framework [103], being highly reliant on international trade and a persistent promoter of trade opening [104]. E-commerce in Sweden is prevalent due to a mail order habit in the state, as well as the high connectivity rate [105]. Another reason concerning disparities among Western and Eastern Europe is attributed to the historical setting. In the early 1990s, the Internet had already registered a broad proliferation in Western Europe, but this expansion was slower for Eastern European nations, which pertained to the Soviet bloc until the early 1990s [106]. Like [70], the e-commerce portion of retail sales is greater in nations where trade is more structured since efficient sellers have shifted quickly toward omnichannel trading. Similarly, [68] confirmed that Western Europe holds three of the leading six e-commerce marketplaces.

\subsection{Panel Data Regression Model Results}

The econometric outcomes with respect to the influence of e-commerce on the employment rate are displayed in Table 4 . Provided that Prob $>$ chi2, and, respectively, the Hausman test is less than 0.05 , then it indicates significance and it is proper to employ a fixed-effect estimator as in $[19,20]$. Furthermore, the redundant fixed-effects tests strongly reject the null hypothesis according to which the effects are redundant. Therefore, the results suggest that the effects are statistically significant, consistent with [78].

Table 4. The outcomes of panel data regression models regarding the impact of e-commerce on the employment rate.

\begin{tabular}{|c|c|c|c|c|c|c|c|}
\hline \multicolumn{2}{|c|}{ Variables } & FE (1) & FE (2) & FE (3) & EGLS (4) & EGLS (5) & EGLS (6) \\
\hline \multicolumn{2}{|c|}{ Constant } & $\begin{array}{c}14.52309 \\
(1.599537)\end{array}$ & $\begin{array}{l}7.240614 \\
(0.93222)\end{array}$ & $\begin{array}{c}11.32949 \\
(1.630056)\end{array}$ & $\begin{array}{c}25.67644^{* * *} \\
(3.38185)\end{array}$ & $\begin{array}{l}13.35725 * \\
(1.82444)\end{array}$ & $\begin{array}{c}19.62158^{* * *} \\
(2.874056)\end{array}$ \\
\hline \multicolumn{2}{|c|}{ VECS } & $\begin{array}{c}0.205061 * * * \\
(3.039233)\end{array}$ & & & $\begin{array}{c}0.211089 * * * \\
(5.699431)\end{array}$ & & \\
\hline \multicolumn{2}{|c|}{ WS } & & $\begin{array}{c}0.25871 * \\
(1.760478)\end{array}$ & & & $\begin{array}{c}0.267748 \text { *** } \\
(3.037512)\end{array}$ & \\
\hline \multicolumn{2}{|c|}{ ECS } & & & $\begin{array}{c}0.350083 \text { *** } \\
(3.478314)\end{array}$ & & & $\begin{array}{c}0.291661 \text { *** } \\
(5.363795)\end{array}$ \\
\hline \multicolumn{2}{|c|}{ GR } & $\begin{array}{c}0.123284 \\
(1.17013)\end{array}$ & $\begin{array}{l}0.134558 \\
(1.46777)\end{array}$ & $\begin{array}{c}0.06267 \\
(0.678264)\end{array}$ & $\begin{array}{c}0.101833 \\
(1.472291)\end{array}$ & $\begin{array}{l}0.161321^{* *} \\
(2.262753)\end{array}$ & $\begin{array}{c}0.077146 \\
(1.242141)\end{array}$ \\
\hline \multicolumn{2}{|c|}{$\mathrm{RD}$} & $\begin{array}{c}1.660746^{* * *} \\
(2.693703)\end{array}$ & $\begin{array}{l}0.809449 * \\
(1.729823)\end{array}$ & $\begin{array}{c}2.532699 * * * \\
(3.458894)\end{array}$ & $\begin{array}{c}1.075271 * * * \\
(2.77842)\end{array}$ & $\begin{array}{c}0.844038 \\
(1.562627)\end{array}$ & $\begin{array}{c}1.780991 \text { *** } \\
(5.69595)\end{array}$ \\
\hline \multicolumn{2}{|c|}{ EICT } & $\begin{array}{c}2.935139 * * * \\
(3.826366)\end{array}$ & $\begin{array}{c}4.095899 * * * \\
(14.58892)\end{array}$ & $\begin{array}{c}2.540249 * * * \\
(3.820456)\end{array}$ & $\begin{array}{c}2.367059 * * * \\
(5.001671)\end{array}$ & $\begin{array}{c}3.420583 * * * \\
(10.45606)\end{array}$ & $\begin{array}{c}2.017769 * * * \\
(6.691394)\end{array}$ \\
\hline \multicolumn{2}{|c|}{ IA } & $\begin{array}{c}0.418635 \text { *** } \\
(4.880449)\end{array}$ & $\begin{array}{c}0.477364 * * * \\
(5.98066)\end{array}$ & $\begin{array}{c}0.431098 \text { *** } \\
(6.356127)\end{array}$ & $\begin{array}{c}0.329374^{* * *} \\
(4.199806)\end{array}$ & $\begin{array}{l}0.43775 * * * \\
(6.005945)\end{array}$ & $\begin{array}{l}0.38171 * * * \\
(5.688293)\end{array}$ \\
\hline \multicolumn{2}{|c|}{ R-squared } & 0.864035 & 0.903143 & 0.860158 & 0.925133 & 0.951757 & 0.924480 \\
\hline \multicolumn{2}{|c|}{ Adjusted R-sq } & 0.844522 & 0.887605 & 0.841789 & 0.914388 & 0.944017 & 0.914561 \\
\hline \multirow{2}{*}{\multicolumn{2}{|c|}{ F-statistic }} & $44.27899 * * *$ & $58.12281 * * *$ & $46.82638^{* * *}$ & $86.10085^{* * *}$ & $122.9726^{* * *}$ & $93.19414^{* * *}$ \\
\hline & & & Redundant I & -Effects Tests & & & \\
\hline \multirow{2}{*}{ Cross-section F } & Statistic & 24.273259 & 30.660376 & 25.300520 & 39.029930 & 52.630590 & 47.828184 \\
\hline & Prob. & 0.0000 & 0.0000 & 0.0000 & 0.0000 & 0.0000 & 0.0000 \\
\hline Cross-section & Statistic & 338.903392 & 355.130863 & 356.886318 & & & \\
\hline Chi-sq & Prob. & 0.0000 & 0.0000 & 0.0000 & & & \\
\hline
\end{tabular}


Table 4. Cont.

\begin{tabular}{|c|c|c|c|c|c|c|}
\hline Variables & FE (1) & FE (2) & FE (3) & EGLS (4) & EGLS (5) & EGLS (6) \\
\hline \multicolumn{7}{|c|}{ Correlated Random-Effects-Hausman Test } \\
\hline Chi-Sq. Statistic & 16.146388 & 22.742373 & 18.180984 & & & \\
\hline Prob. & 0.0064 & 0.0004 & 0.0027 & & & \\
\hline Sample (adjusted) & 2010-2019 & 2011-2019 & 2010-2019 & 2010-2019 & 2011-2019 & 2010-2019 \\
\hline Periods included & 10 & 9 & 10 & 10 & 9 & 10 \\
\hline Cross-sections included & 27 & 26 & 27 & 27 & 26 & 27 \\
\hline Total panel (unbalanced) obs. & 248 & 218 & 268 & 248 & 218 & 268 \\
\hline
\end{tabular}

Source: Authors' calculations. Notes: ${ }^{* *}, * *$, and ${ }^{*}$ denote statistical significance at 1,5 , and $10 \%$ respectively. Statistics in ( ) exhibit $\mathrm{t}$-statistic. White cross-section standard errors and covariance (d.f. corrected) are considered. FE denotes panel data fixed-effects regression (cross section fixed-dummy variables). EGLS signify panel data estimated generalized least squares regression (cross section weights). For the description of measures, please see Table 1.

The whole estimated coefficients for e-commerce variables are statistically significant and demonstrate that one percentage change in enterprises' total turnover from e-commerce sales, enterprises' turnover from web sales, and enterprises with e-commerce sales of at least 1\% turnover will drive and increase by 0.205 (Equation (1)), 0.258 (Equation (2)), and 0.350 (Equation (3)) percentage points in the employment rate. Hence, as compared to e-commerce sales, web sales exert a higher influence on employment rate. E-commerce shifts previous non-market behaviors such as driving to physical stores, identifying the proper product, or waiting to pay into remunerated jobs to encourage accessibility and permit customers to use that time for different operations [107]. Therefore, when individuals buy online, duties that customers once did are actually completed by warehouse personnel and truck drivers [108]. For instance, [109] regarded e-commerce as a system for transforming unpaid household hours into paid market hours, if the productivity benefits are appropriate.

Accordingly, the whole formulated research hypotheses $(\mathrm{H} 1-\mathrm{H} 3)$ are supported. The outcomes are in line with $[5,11]$, which demonstrated that ICT applications do not damage employment. With reference to the magnitude of the coefficients, the values are nearly those reported by [12]. Besides, all the country-level control variables positively influence the employment rate.

Furthermore, in order to control for heteroscedasticity or auto-correlation problems, the panel data estimated generalized least squares (EGLS) regressions are estimated, similar to $[14,23,24]$. In view of the results reported in Table 4, namely Equations (7)-(9), the main result is that the entire e-commerce measures reinforce the statistically significant positive effects on employment rate at the $1 \%$ level of significance. As well, the high value related to R-squared reveals that the estimated panel data regression models have a good general fit. Therefore, the results reinforce [43] according to whom e-business operations stimulate employment needs since additional computer workers are essential to organize, support, and supervise the supplementary equipment that electronic commerce entails. Furthermore, consistent with [45], e-commerce undertakings involve additional graphic artists, stylists, journalists, and editors. Besides, several service-related jobs can be externalized to developing nations, whereas fresh perspectives arise for self-employment and entrepreneurs [63].

In addition, we check if the quantitative outcomes reported in Table 4 are affected by the multicollinearity issue that diminishes the accuracy of the estimated coefficients and weakens the statistical power of the regression models. With the purpose of identifying multicollinearity among predictors, the variance inflation factors (VIFs) are exhibited in Table 5. VIF evaluates the extent by which the variance of a parameter estimator is inflated attributable to predictor variables being correlated with each other, instead of being orthogonal [110]. The VIF is based on the amount of variance the $i$ th explanatory variable shares with the different independent variables in the model [111]. The greater the values of VIFs, the more collinear the explanatory variables [112]. A guideline for assessing VIFs is to be concerned with any value greater than 10 , this rule being equivalent to an 
R-squared larger than 0.90 [113]. Nevertheless, the whole VIFs revealed in Table 5 are less than 10, supporting the fact that the empirical outcomes are free of multicollinearity.

Table 5. Centered variance inflation factors (VIFs) for panel data regression models regarding the impact of e-commerce on the employment rate.

\begin{tabular}{ccccccc}
\hline Variables & FE (1) & FE (2) & FE (3) & EGLS (4) & EGLS (5) & EGLS (6) \\
\hline Constant & N/A & N/A & N/A & N/A & N/A & N/A \\
VECS & 4.967194 & & & 1.266167 & & \\
WS & & 1.489787 & & & 1.106549 & \\
ECS & & & 8.178458 & & & 1.745792 \\
GR & 1.386507 & 1.931675 & 1.349236 & 1.261658 & 1.233247 & 2.224875 \\
RD & 4.896065 & 1.142205 & 6.586133 & 1.283792 & 1.404521 & 1.177523 \\
EICT & 2.166514 & 1.479403 & 2.018815 & 1.02727 & 1.492749 & 1.530465 \\
IA & 1.866824 & 1.87074 & 1.410018 & 1.759372 & 1.487427 & 2.073989 \\
\hline
\end{tabular}

Source: Authors' calculations. FE denotes panel data fixed-effects regression (cross section fixed-dummy variables). EGLS signify panel data estimated generalized least squares regression (cross section weights). For the description of measures, please see Table 1.

To check for robustness of quantitative results, Tables 6-8 exhibit the results through the method of moments quantile regression.

Table 6. The outcomes of method of moments quantile regression models with fixed effects (MM-QR) regarding the impact of enterprises' total turnover from e-commerce sales on the employment rate.

\begin{tabular}{cccccccccc}
\hline Variables & $\boldsymbol{\tau}=\mathbf{0 . 1}$ & $\boldsymbol{\tau}=\mathbf{0 . 2}$ & $\boldsymbol{\tau}=\mathbf{0 . 3}$ & $\boldsymbol{\tau}=\mathbf{0 . 4}$ & $\boldsymbol{\tau}=\mathbf{0 . 5}$ & $\boldsymbol{\tau}=\mathbf{0 . 6}$ & $\boldsymbol{\tau}=\mathbf{0 . 7}$ & $\boldsymbol{\tau}=\mathbf{0 . 8}$ & $\boldsymbol{\tau}=\mathbf{0 . 9}$ \\
\hline \multirow{2}{*}{ VECS } & $0.19119^{*}$ & $0.19438^{* *}$ & $0.19824^{* *}$ & $0.20222^{* * *}$ & $0.20515^{* * *}$ & $0.20925^{* * *}$ & $0.21235^{* * *}$ & $0.21551^{* * *}$ & $0.21991^{*}$ \\
& $(1.64527)$ & $(1.97138)$ & $(2.46921)$ & $(3.00292)$ & $(3.20741)$ & $(3.00971)$ & $(2.64337)$ & $(2.26747)$ & $(1.84452)$ \\
& 0.11631 & 0.11792 & 0.11985 & 0.12186 & 0.12333 & 0.12539 & 0.12695 & 0.12853 & 0.13075 \\
GR & $(0.79446)$ & $(0.94920)$ & $(1.18497)$ & $(1.43635)$ & $(1.53057)$ & $(1.43157)$ & $(1.25431)$ & $(1.07342)$ & $(0.87044)$ \\
& $3.74542^{* *}$ & $3.26557^{* *}$ & $2.68641^{* *}$ & $2.08718^{* *}$ & $1.64793^{*}$ & 1.03064 & 0.56444 & 0.09076 & -0.57124 \\
RD & $(2.10302)$ & $(2.16221)$ & $(2.16889)$ & $(1.99245)$ & $(1.65000)$ & $(0.95334)$ & $(0.45591)$ & $(0.06223)$ & $(-0.31352)$ \\
& $2.67445^{* * *}$ & $2.73446^{* * *}$ & $2.80688^{* * *}$ & $2.88181^{* * *}$ & $2.93674^{* * *}$ & $3.01393^{* * *}$ & $3.07223^{* * *}$ & $3.13146^{* * *}$ & $3.21425^{* * *}$ \\
EICT & $(3.31288)$ & $(3.99205)$ & $(5.03012)$ & $(6.15305)$ & $(6.60004)$ & $(6.23324)$ & $(5.50259)$ & $(4.74228)$ & $(3.88161)$ \\
& $0.48250^{* *}$ & $0.46780^{* * *}$ & $0.45005^{* * *}$ & $0.43170^{* * *}$ & $0.41824^{* * *}$ & $0.39933^{* * *}$ & $0.38505^{* * *}$ & $0.37054^{* *}$ & $0.35026^{*}$ \\
IA & $(2.46962)$ & $(2.82189)$ & $(3.33206)$ & $(3.80744)$ & $(3.88249)$ & $(3.41152)$ & $(2.84927)$ & $(2.31856)$ & $(1.74788)$ \\
\hline \multirow{2}{*}{$\mathrm{N}$} & 248 & 248 & 248 & 248 & 248 & 248 & 248 & 248 & 248 \\
\hline
\end{tabular}

Source: Authors' calculations. Notes: ${ }^{* * *},{ }^{* *}$, and ${ }^{*}$ denote statistical significance at 1,5 , and $10 \%$ respectively. Statistics in ( ) exhibit z-statistic. For the description of measures, please see Table 1.

Table 7. The outcomes of method of moments quantile regression models with fixed effects (MM-QR) regarding the impact of enterprises' turnover from web sales on the employment rate.

\begin{tabular}{|c|c|c|c|c|c|c|c|c|c|}
\hline Variables & $\tau=0.1$ & $\tau=0.2$ & $\tau=0.3$ & $\tau=0.4$ & $\tau=0.5$ & $\tau=0.6$ & $\tau=0.7$ & $\tau=0.8$ & $\tau=0.9$ \\
\hline WS & $\begin{array}{c}0.12435 \\
(0.59634)\end{array}$ & $\begin{array}{c}0.14975 \\
(0.81976)\end{array}$ & $\begin{array}{c}0.18304 \\
(1.18944)\end{array}$ & $\begin{array}{c}0.21395 \\
(1.58039)\end{array}$ & $\begin{array}{c}0.25312^{* *} \\
(1.98019)\end{array}$ & $\begin{array}{c}0.29159 * * \\
(2.07592)\end{array}$ & $\begin{array}{c}0.32699 * * \\
(1.97055)\end{array}$ & $\begin{array}{l}0.36446 * \\
(1.80674)\end{array}$ & $\begin{array}{c}0.40753 \\
(1.63546)\end{array}$ \\
\hline GR & $\begin{array}{c}0.14871 \\
(1.20522)\end{array}$ & $\begin{array}{c}0.14604 \\
(1.35179)\end{array}$ & $\begin{array}{c}0.14253 \\
(1.56939)\end{array}$ & $\begin{array}{l}0.13927^{*} \\
(1.75139)\end{array}$ & $\begin{array}{l}0.13515^{*} \\
(1.80324)\end{array}$ & $\begin{array}{c}0.13109 \\
(1.58870)\end{array}$ & $\begin{array}{c}0.12736 \\
(1.30288)\end{array}$ & $\begin{array}{c}0.12342 \\
(1.03605)\end{array}$ & $\begin{array}{c}0.11888 \\
(0.80689)\end{array}$ \\
\hline $\mathrm{RD}$ & $\begin{array}{c}2.40307 \\
(1.48724)\end{array}$ & $\begin{array}{c}2.10175 \\
(1.48401)\end{array}$ & $\begin{array}{c}1.70696 \\
(1.42811)\end{array}$ & $\begin{array}{c}1.34035 \\
(1.26868)\end{array}$ & $\begin{array}{c}0.87572 \\
(0.87621)\end{array}$ & $\begin{array}{c}0.41945 \\
(0.38269)\end{array}$ & $\begin{array}{c}-0.00033 \\
(-0.00026)\end{array}$ & $\begin{array}{c}-0.44483 \\
(-0.28404)\end{array}$ & $\begin{array}{c}-0.95565 \\
(-0.49450)\end{array}$ \\
\hline EICT & $\begin{array}{c}4.38298^{* * *} \\
(6.10711)\end{array}$ & $\begin{array}{c}4.32870^{* * *} \\
(6.88708)\end{array}$ & $\begin{array}{c}4.25758^{* * *} \\
(8.05106)\end{array}$ & $\begin{array}{c}4.19153 * * * \\
(9.03529)\end{array}$ & $\begin{array}{c}4.10784^{* * *} \\
(9.38841)\end{array}$ & $\begin{array}{c}4.02564^{* * *} \\
(8.36302)\end{array}$ & $\begin{array}{c}3.95002 * * * \\
(6.93447)\end{array}$ & $\begin{array}{c}3.86995^{* * *} \\
(5.58070)\end{array}$ & $\begin{array}{c}3.77793 \text { *** } \\
(4.40717)\end{array}$ \\
\hline IA & $\begin{array}{c}0.52312 * * * * \\
(3.17416)\end{array}$ & $\begin{array}{c}0.51447^{* * *} \\
(3.56529)\end{array}$ & $\begin{array}{c}0.50313^{* * * *} \\
(4.14675)\end{array}$ & $\begin{array}{c}0.49261^{* * * *} \\
(4.63432)\end{array}$ & $\begin{array}{c}0.47927 * * * \\
(4.78304)\end{array}$ & $\begin{array}{c}0.46617^{* * * *} \\
(4.22647)\end{array}$ & $\begin{array}{c}0.45411 * * * \\
(3.47642)\end{array}$ & $\begin{array}{c}0.44135^{* * * *} \\
(2.77341)\end{array}$ & $\begin{array}{l}0.42668 \text { *** } \\
(2.16812)\end{array}$ \\
\hline $\mathrm{N}$ & 218 & 218 & 218 & 218 & 218 & 218 & 218 & 218 & 218 \\
\hline
\end{tabular}

Source: Authors' calculations. Notes: ${ }^{* * *}, * *$, and ${ }^{*}$ denote statistical significance at 1,5 , and $10 \%$ respectively. Statistics in ( ) exhibit z-statistic. For the description of measures, please see Table 1. 
Table 8. The outcomes of method of moments quantile regression models with fixed effects (MM-QR) regarding the impact of percentage of enterprises with e-commerce sales of at least $1 \%$ turnover on the employment rate.

\begin{tabular}{cccccccccc}
\hline Variables & $\boldsymbol{\tau}=\mathbf{0 . 1}$ & $\boldsymbol{\tau}=\mathbf{0 . 2}$ & $\boldsymbol{\tau}=\mathbf{0 . 3}$ & $\boldsymbol{\tau}=\mathbf{0 . 4}$ & $\boldsymbol{\tau}=\mathbf{0 . 5}$ & $\boldsymbol{\tau}=\mathbf{0 . 6}$ & $\boldsymbol{\tau}=\mathbf{0 . 7}$ & $\boldsymbol{\tau}=\mathbf{0 . 8}$ & $\boldsymbol{\tau}=\mathbf{0 . 9}$ \\
\hline ECS & $0.34105^{* * *}$ & $0.34372^{* * *}$ & $0.34546^{* * *}$ & $0.34714^{* * *}$ & $0.35002^{* * *}$ & $0.35261^{* * *}$ & $0.35501^{* * *}$ & $0.35701^{* * *}$ & $0.35955^{* * *}$ \\
& $(2.84349)$ & $(3.52389)$ & $(4.07563)$ & $(4.65043)$ & $(5.35569)$ & $(5.16064)$ & $(4.44848)$ & $(3.81529)$ & $(3.14527)$ \\
GR & 0.08272 & 0.07680 & 0.07294 & 0.06920 & 0.06281 & 0.05707 & 0.05173 & 0.04729 & 0.04166 \\
& $(0.61925)$ & $(0.70700)$ & $(0.77260)$ & $(0.83217)$ & $(0.86257)$ & $(0.74962)$ & $(0.58188)$ & $(0.45381)$ & $(0.32722)$ \\
RD & $3.45256^{* *}$ & $3.18092^{* *}$ & $3.00358^{* *}$ & $2.83216^{* * *}$ & $2.53931^{* * *}$ & $2.27559^{* *}$ & $2.03070^{*}$ & 1.82730 & 1.56873 \\
& $(2.03530)$ & $(2.30732)$ & $(2.50662)$ & $(2.67929)$ & $(2.73682)$ & $(2.34841)$ & $(1.79751)$ & $(1.38144)$ & $(0.97127)$ \\
EICT & $1.90379^{* *}$ & $2.09174^{* * *}$ & $2.21444^{* * *}$ & $2.33305^{* * *}$ & $2.53568^{* * *}$ & $2.71815^{* * *}$ & $2.88758^{* * *}$ & $3.02832^{* * *}$ & $3.20722^{* * *}$ \\
& $(2.25704)$ & $(3.05401)$ & $(3.71809)$ & $(4.42731)$ & $(5.45969)$ & $(5.61261)$ & $(5.12996)$ & $(4.60701)$ & $(4.00064)$ \\
IA & $0.57282^{* * *}$ & $0.53097^{* * *}$ & $0.50365^{* * *}$ & $0.47724^{* * *}$ & $0.43212^{* * *}$ & $0.39148^{* * *}$ & $0.35375^{* * *}$ & $0.32242^{* *}$ & 0.28258 \\
& $(2.95090)$ & $(3.36831)$ & $(3.67428)$ & $(3.93582)$ & $(4.04487)$ & $(3.51380)$ & $(2.73117)$ & $(2.13118)$ & $(1.53142)$ \\
\hline N & 268 & 268 & 268 & 268 & 268 & 268 & 268 & 268 & 268 \\
\hline
\end{tabular}

Source: Authors' calculations. Notes: ${ }^{* *},{ }^{* *}$, and ${ }^{*}$ denote statistical significance at 1,5 , and $10 \%$ respectively. Statistics in ( ) exhibit z-statistic. For the description of measures, please see Table 1.

Accordingly, both enterprises' total turnover from e-commerce sales and the percentage of enterprises with e-commerce sales of at least $1 \%$ turnover positively influence employment rate for all quintiles. However, in the case of enterprises' turnover from web sales, the influence is positive and statistically significant, but only for the quintiles ranging from $0.5-0.8$. As such, the research hypotheses are confirmed. Hence, the results support [44], which claimed that expanded demand and output will drive indirect creation of jobs. Similar to [69], e-commerce promotes trade, as well as exports, entrepreneurship, and employment prospects at the regional and national levels.

\section{Concluding Remarks and Policy Implications}

Nowadays, the labor market, the permanent confrontation of demand with job offers, and the appearance of unemployment or the surplus of jobs in certain sectors of activity or development regions are extremely sensitive issues in the economic, social, and cultural development of a country or region. Under such circumstances, the impact of government measures and the local or central administration to stimulate or restrict some fields and to regulate the functioning of some entities will influence these indicators directly and immediately.

We have discussed the results of several studies highlighting that economic development, specifically the value of GDP per capita, increases along with technological progress and the widespread digitalization of all areas of our lives, which could lead to the replacement of human capital and, therefore, to the decrease of the employment rate. The level of this correlation could support the hypothesis that increased employment could be driven more by structural changes than by those related to the GDP level [74]. Through the estimated quantitative models, similar to prior studies [35-37], we demonstrated that employment of the population depends on the economic development, which is capable of creating new jobs in different sectors and development regions.

Through globalization, digitalization, and invigoration of foreign investments, including investments in research and development, in all countries, there is a continuous process of disappearance of certain jobs and appearance of other jobs, usually associated with new processes or business models resulting from R\&D. However, they are not synchronized [33] since they determine either higher unemployment or higher employment alternatively. We believe that although for developing countries this problem may be a threat, the increased employment will certainly reduce the poverty of the population [34].

Furthermore, policies and regulations that act on the labor market, in the field of employment, can be enforced to reduce or compensate for the negative effects of globalization or global economic crisis situations, such as the health crisis generated by the pandemic in the past two years. Thus, if unemployment reflects a mismatch between labor supply and demand at a given time in the labor market, employment growth reflects an increase 
in labor demand [77], which can be satisfied by encouraging people to work, to enter the labor market [10], and to take up employment opportunities.

Our study demonstrates the strong dependence of the population on the development of ICT, internet communication, and the widespread use of mobile devices, and brings forward this argument to all decision-makers involved in organizational, regional, or national development. In order to meet the requirements of knowledge, skills, and necessary infrastructure, this framework requires investments in organizational and human capital [40]. We also consider that supporting small and medium-sized enterprises (SMEs) can be very effective, because they bring innovations in the business environment, which creates jobs that require new skills, expertise, and a high level of education.

Commerce is the "circulatory apparatus" of the economic system and human activity, which also involves employment, and we have found that it accompanies and determines not only the economic development, but also major changes in human society. E-commerce has taken over more and more of the commerce activity (72.9\% in 2021) and influences the employment of the population directly and positively, according to our econometric study. However, all these aspects can lead to the migration of the population from one region to another in search of a suitable job, or even to emigration to other countries, where the salary packages may be more attractive.

Our empirical research shows that all factors we have considered impact employment directly and positively. This means that the continuous development of ICT in all sectors of activity, Internet communication and e-commerce, the development of secure online payment platforms, and social networks using all types of mobile devices, will lead to lasting economic growth and will increase the demand for products once the population's confidence in the use of ICT tools is built. This will lead to a diversification and an increase in production, new jobs will be created, and hence the employment rate will increase, provided there is a higher level of education $[65,86]$. Public policies for monitoring all these indicators that directly influence the employment rate are particularly important and sensitive for the economic and social development of a country or community (e.g., EU).

Ultimately, yet importantly, we consider our study makes both a theoretical and a practical contribution to the identification and description of some crucial aspects in the study of the labor market. The theoretical contribution of our study consists of the fact that it discusses a problem of great relevance for all countries nowadays, during a health and economic crisis globally - the problem of employment and its dependence on the factors we consider in this study. E-commerce has largely saved jobs, reduced expenses, and provided employment through its collateral activities (online payment platforms, freightcourier, related software, IoT tools and other ICT tools that require implementation and maintenance, including manufacturing). The practical contribution of our study consists in the fact that, demonstrating the direct and positive impact of the considered factors on the employment rate of the population, we offer a knowledge tool to all decision-makers that can influence and stimulate these factors to ensure good economic, social, and cultural development of their organizations, regions, countries, or communities.

Furthermore, our study is not free of limitations. First, we did not take into account a number of factors that may influence the online sales process. Although we provided information on how factors such as e-commerce, ICT, GDP, and R\&D generate jobs directly and indirectly and increase the employment rate of the population, our study did not focus on their very different distribution both at the territorial level and for population groups in the economy. These will determine movements of the population groups in search of a more suitable job, which can have economic and social implications. Second, besides the technical support of the ICT infrastructure, the entire development of e-commerce must build trust with the customers, which is particularly important in the context of online sales. This matter should be analyzed because it can decisively influence the purchase of a product from such a supplier. Moreover, the different characteristics of Internet access for users and companies (costs, speed, security) in different countries can also have a strong impact on the development and expansion of ICT and e-commerce, which in turn will 
affect employment. To these are added public policies to stimulate digitization, reduce Internet costs, promote new online sales and payment tools in different countries, develop and promote mobile telephony [67], and even train or specialize human resources in related fields (e.g., communication and public relations, ICT, cyber security, marketing). These policies will lead to a considerable increase in online sales, with all its implications. Third, comfort and increased customer satisfaction are tangible by gaining customers' trust [46], through the appreciation of each customer by the seller and through reliable information and quality sales service, offering many payment options.

Finally, these facts can become objectives for future research because e-commerce will grow continuously and will affect the economic development, the employment of the population, and perhaps even the specialization and migration of the population.

Author Contributions: Conceptualization, S.C.G., M.A.B. and L.N.S.; methodology, S.C.G., M.A.B. and L.N.S.; software, S.C.G., M.A.B. and L.N.S.; validation, S.C.G., M.A.B. and L.N.S.; formal analysis, S.C.G., M.A.B. and L.N.S.; investigation, S.C.G., M.A.B. and L.N.S.; resources, S.C.G., M.A.B. and L.N.S.; data curation, S.C.G., M.A.B. and L.N.S.; writing-original draft preparation, S.C.G., M.A.B. and L.N.S.; writing-review and editing, S.C.G., M.A.B. and L.N.S.; visualization, S.C.G., M.A.B. and L.N.S.; supervision, Ș.C.G., M.A.B. and L.N.S.; project administration, S.C.G., M.A.B. and L.N.S.; funding acquisition, S.C.G., M.A.B. and L.N.S. All authors have read and agreed to the published version of the manuscript.

Funding: This research received no external funding.

Institutional Review Board Statement: Not applicable.

Informed Consent Statement: Not applicable.

Data Availability Statement: Not applicable.

Conflicts of Interest: The authors declare no conflict of interest.

\section{Appendix A}

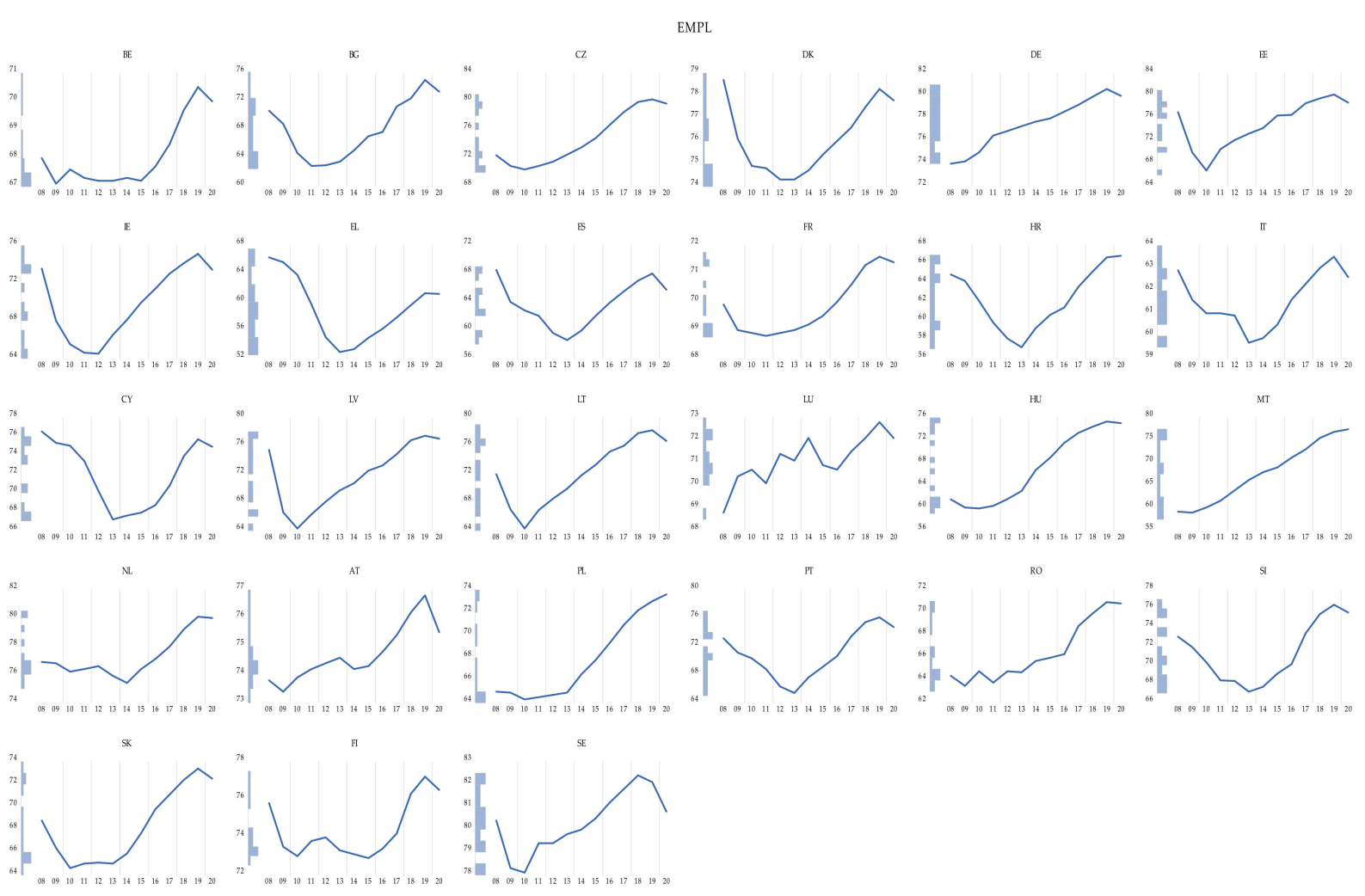

Figure A1. The evolution of employment rate. Source: Authors' work. 


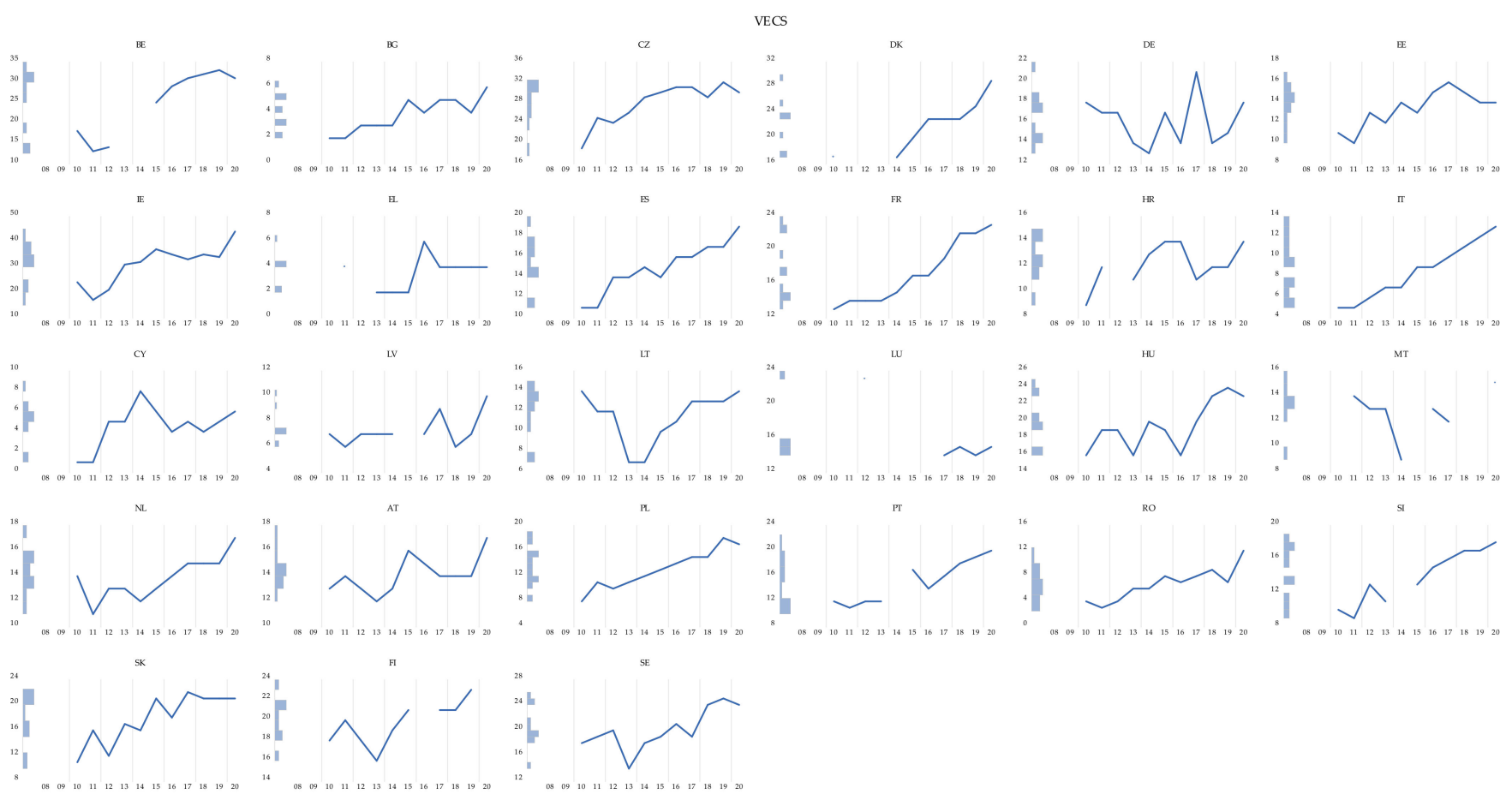

Figure A2. The evolution of enterprises' total turnover from e-commerce sales. Source: Authors' work.

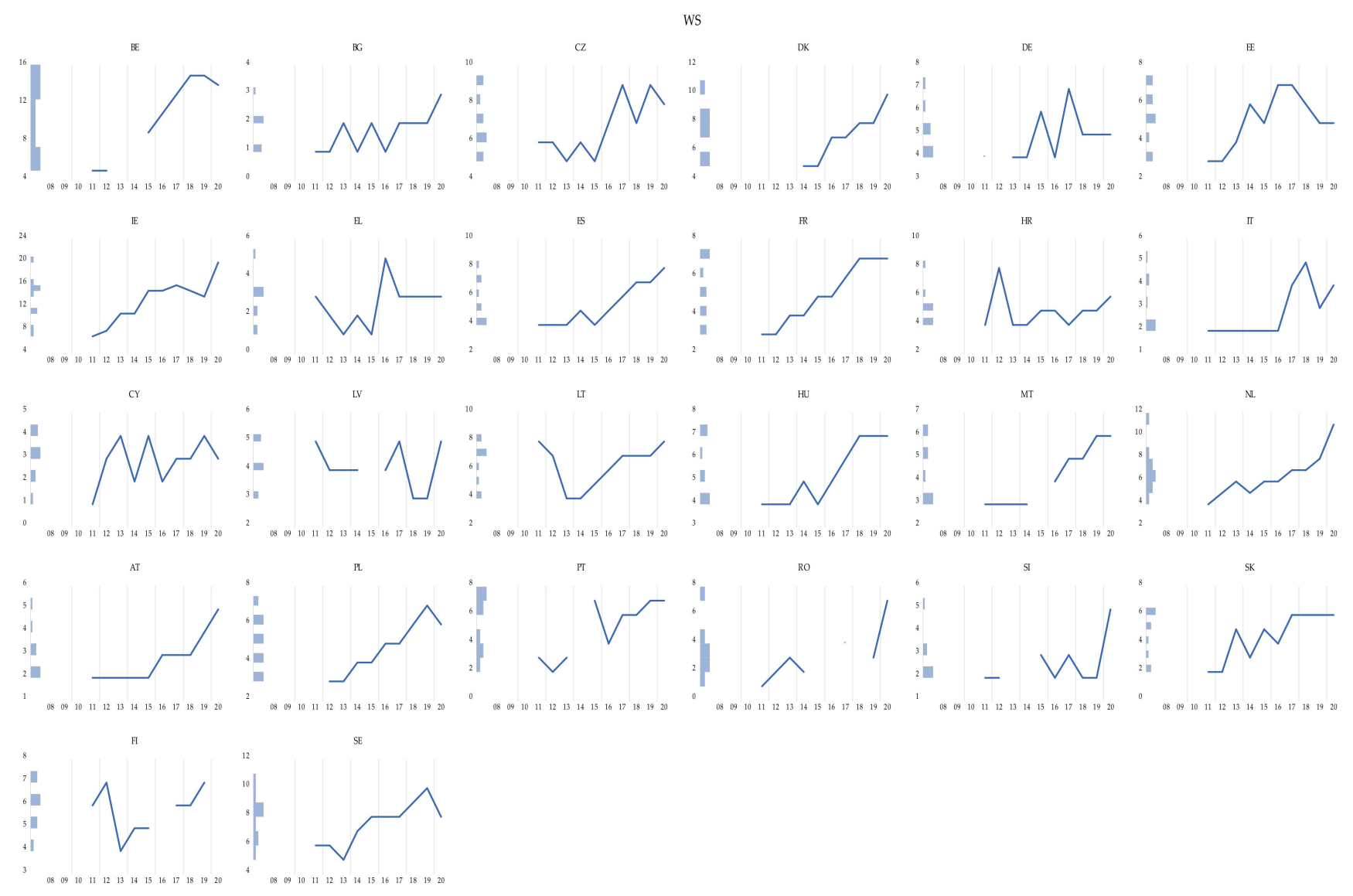

Figure A3. The evolution of enterprises' turnover from web sales. Source: Authors' work. 


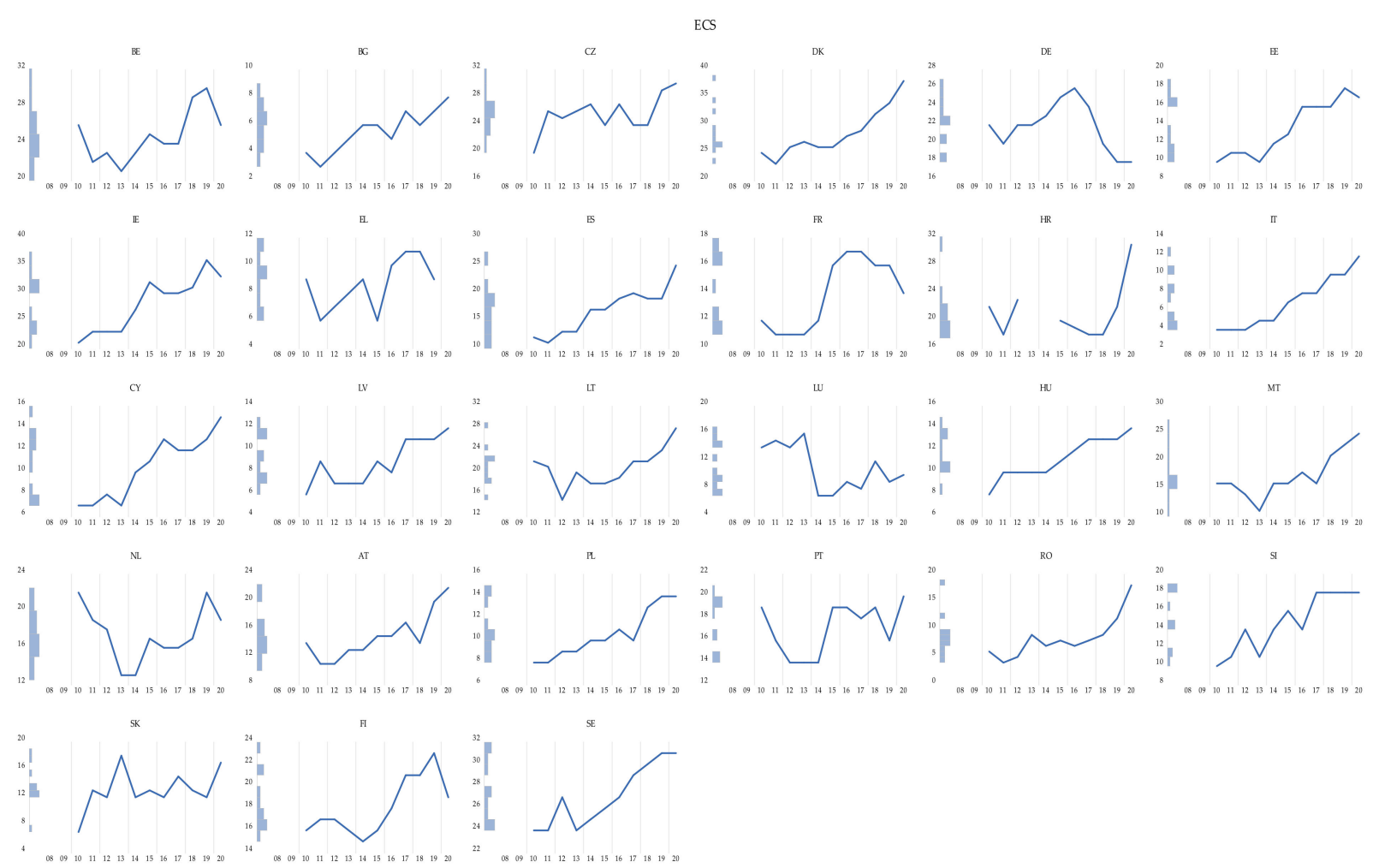

Figure A4. The evolution of percentage of enterprises with e-commerce sales of at least 1\% turnover. Source: Authors' work.

\section{Appendix B}

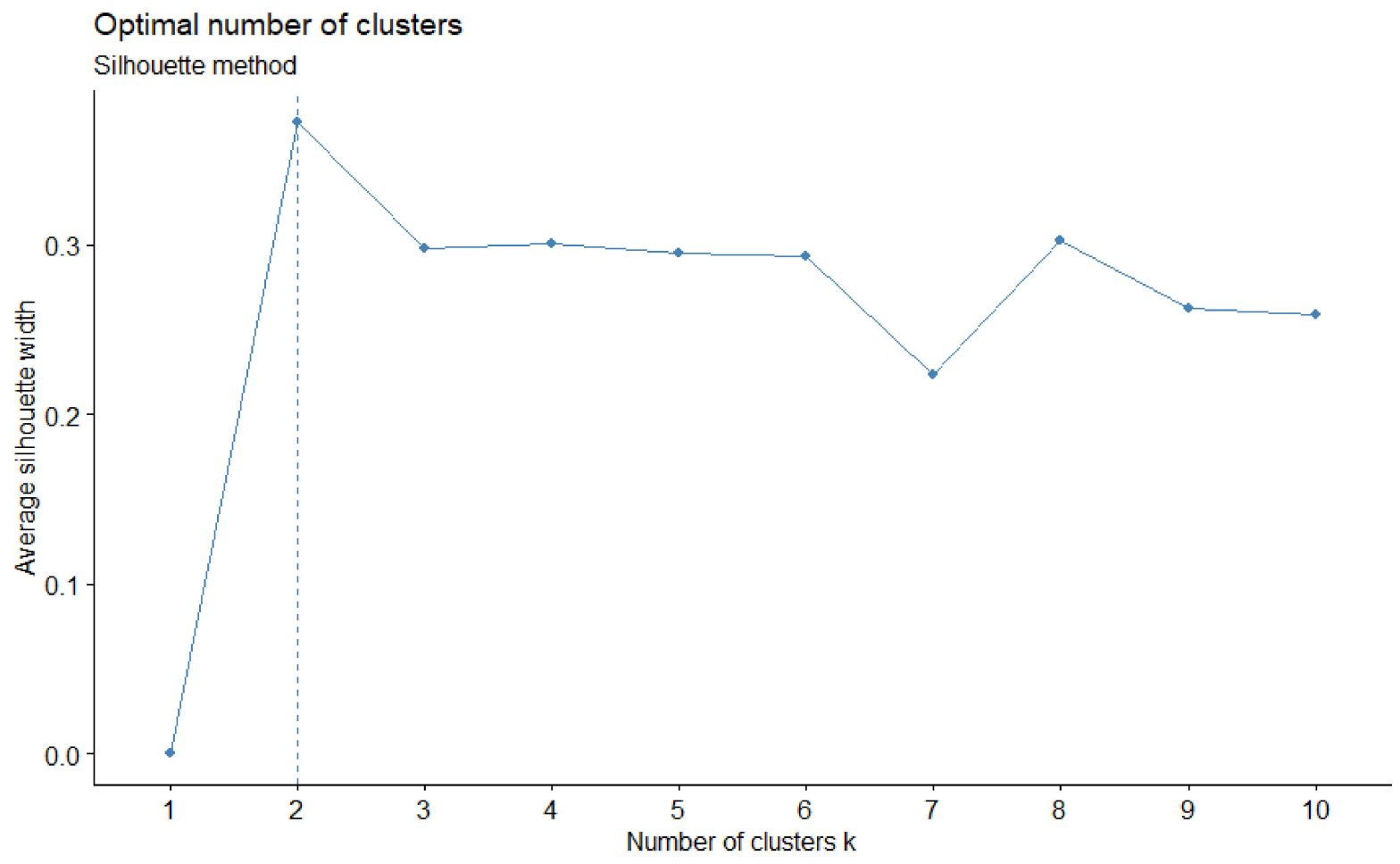

Figure A5. Optimal number of clusters through silhouette method for 2010. Source: Authors' work. 


\section{Optimal number of clusters}

Silhouette method

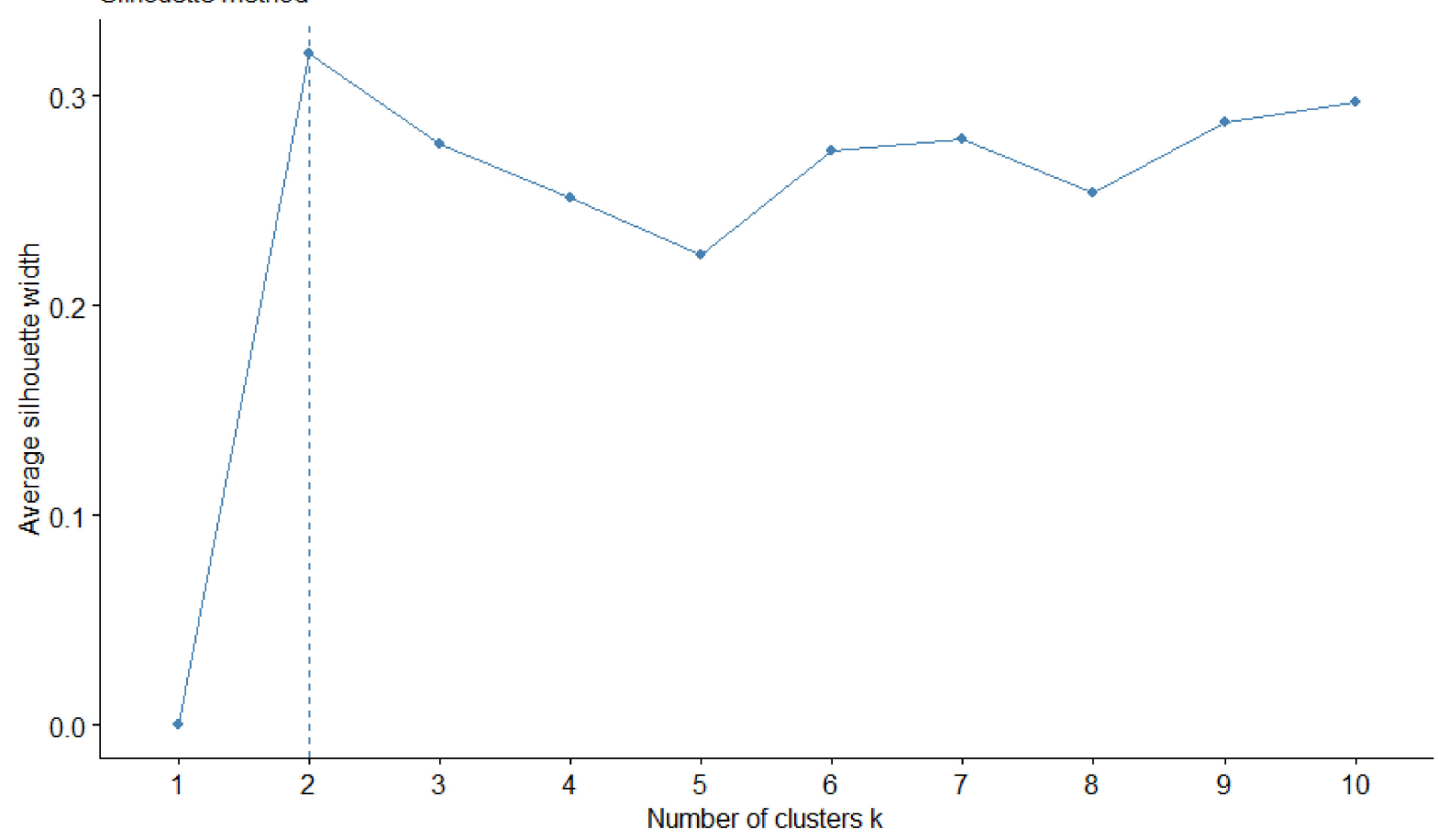

Figure A6. Optimal number of clusters through silhouette method for 2015. Source: Authors' work.

\section{Optimal number of clusters}

Silhouette method

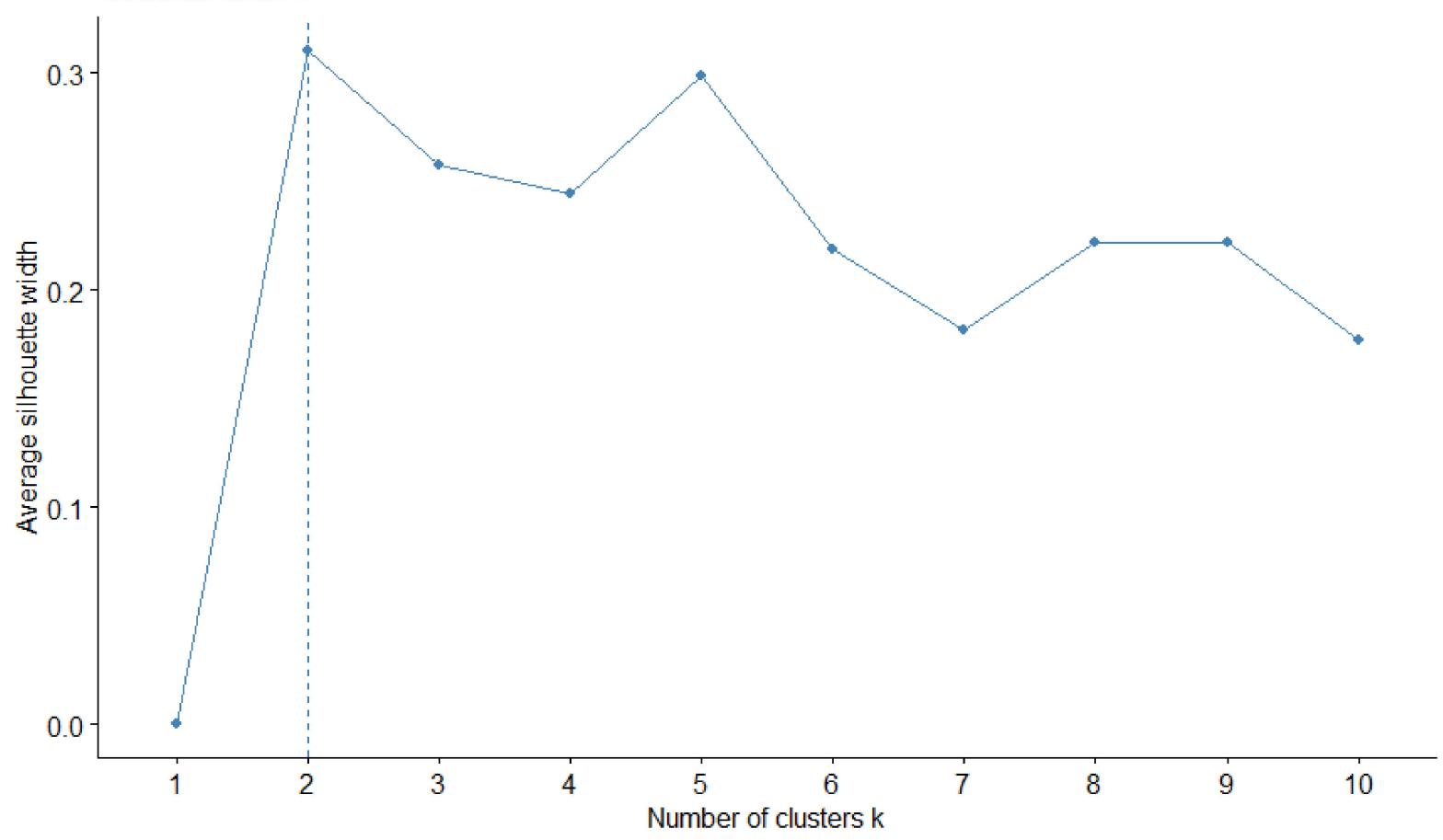

Figure A7. Optimal number of clusters through silhouette method for 2017. Source: Authors' work. 


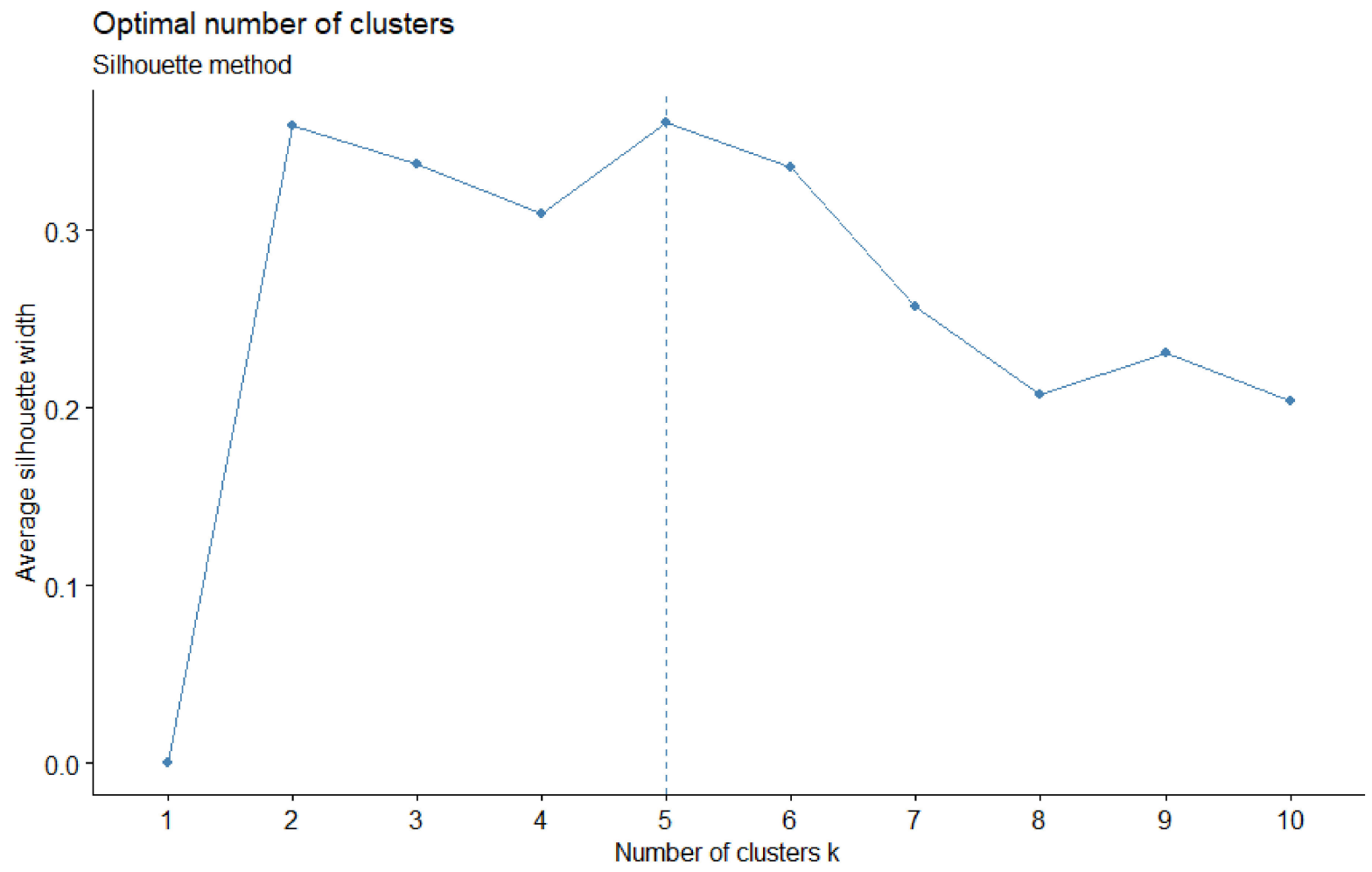

Figure A8. Optimal number of clusters through silhouette method for 2019. Source: Authors' work.

\section{References}

1. Kapsos, S. The employment intensity of growth: Trends and macroeconomic determinants. Employ. Strategy Pap. 2005, 143-201.

2. United Nations. Transforming our World: The 2030 Agenda for Sustainable Development; United Nations: New York, NY, USA, 2015.

3. European Commission. EUROPE 2020 a Strategy for Smart, Sustainable and Inclusive Growth—COM(2010) 2020 Final; Publications Office of the European Union: Luxembourg, 2020.

4. European Commission. A Digital Single Market Strategy for Europe-COM(2015) 192 Final; Publications Office of the European Union: Luxembourg, 2015.

5. Biagi, F.; Falk, M. The impact of ICT and e-commerce on employment in Europe. J. Policy Model 2017, 39, 1-18. [CrossRef]

6. Lone, S.; Harboul, N.; Weltevreden, J.W.J. 2021 European E-Commerce Report; Amsterdam University of Applied Sciences: Amsterdam, The Netherlands; Ecommerce Europe: Brussels, Belgium, 2021.

7. World Economic Forum. The Future of Jobs Report 2020; World Economic Forum: Cologny, Switzerland, 2020.

8. Zatonatska, T.; Fedirko, O. Modeling of the E-Commerce Impact on the Employment in EU. In Proceedings of the 2019 IEEE International Conference on Advanced Trends in Information Theory (ATIT), Kyiv, Ukraine, 18-20 December 2019.

9. Zoroja, J.; Klopotan, I.; Ana-Marija, S. Quality of E-commerce practices in European enterprises: Cluster analysis approach. INDECS 2020, 18, 312-326. [CrossRef]

10. Elhorst, J.P. The mystery of regional unemployment differentials: Theoretical and empirical explanations. J. Econ. Surv. 2003, 17, 709-748. [CrossRef]

11. Pantea, S.; Sabadash, A.; Biagi, F. Are ICT displacing workers in the short run? Evidence from seven European countries. Inf. Econ. Policy 2017, 39, 36-44. [CrossRef]

12. Falk, M.; Hagsten, E. E-commerce trends and impacts across Europe. Int. J. Prod. Econ. 2015, 170, 357-369. [CrossRef]

13. Laitsou, E.; Kargas, A.; Varoutas, D. The impact of ICT on economic growth of Greece and EU-28 under economic crisis. In Proceedings of the 2017 Internet of Things Business Models, Users, and Networks, Aalborg University, Copenhagen, Denmark, 23-24 November 2017.

14. Hanclova, J.; Doucek, P.; Fischer, J.; Vltavska, K. Does ICT capital affect economic growth in the EU-15 and EU-12 countries? J. Bus. Econ. Manag. 2016, 16, 387-406. [CrossRef]

15. Antonopoulos, C.; Sakellaris, P. The contribution of information and communication technology investments to Greek economic growth: An analytical growth accounting framework. Inf. Econ. Policy 2009, 21, 171-191. [CrossRef]

16. European Commission. The European Pillar of Social Rights Action Plan; Publications Office of the European Union: Luxembourg, 2021.

17. Ward, M.R.; Zheng, S. Mobile telecommunications service and economic growth: Evidence from China. Telecommun. Policy 2016, 40, 89-101. [CrossRef] 
18. Shahiduzzaman, M.; Alam, K. Information technology and its changing roles to economic growth and productivity in Australia. Telecommun. Policy 2014, 38, 125-135. [CrossRef]

19. Hodrab, R.; Maitah, M.; Smutka, L. The effect of information and communication technology on economic growth: Arab world case. Int. J. Trade Econ. Financ. Issue 2016, 6, 765-775.

20. Nasab, E.H.; Aghaei, M. The effect of ICT on economic growth: Further evidence. Int. J. Bus. Adm. 2009, 5, 46-56.

21. Purnama, Y.A.; Mitomo, H. The impact of ICT on regional economic growth: Empirical evidence from 34 provinces of Indonesia. In Proceedings of the 29th European Regional Conference of the International Telecommunications Society (ITS): “Towards a Digital Future: Turning Technology into Markets?", Trento, Italy, 1-4 August 2018.

22. Peng, G.; Wang, Y.; Han, G. Information technology and employment: The impact of job tasks and worker skills. Ind. Relat. J. 2018, 60, 201-223. [CrossRef]

23. Sepehrdoust, H.; Khodaee, H. The impact of information and communication technology on employment of selected OIC countries. Afr. J. Bus. Manag. 2016, 7, 4149-4154. [CrossRef]

24. Evangelista, R.; Guerrieri, P.; Meliciani, V. The economic impact of digital technologies in Europe. Econ. Innov. New Technol. 2014, 23, 802-824. [CrossRef]

25. Bach, M.P. Exploring information and communications technology adoption in enterprises and its impact on innovation performance of European countries. Ekonomický časopis 2014, 62, 335-362.

26. Abdollahpouri, M. ICT as a sustainable economic solution for emerging countries. WIT Trans. Ecol. Environ. 2016, 210, 337-344. [CrossRef]

27. Kumar, V.; Arif, T.; Malik, M.B. Role of ICT in driving e-commerce business in developing countries. In Proceedings of the National Conference on Recent Innovations \& Advancements in Information Technology, Department of Information Technology, BGSB University, Rajour, India, 26-27 November 2014.

28. Jehangir, M.; Dominic, P.D.D.; Naseebullah, N.; Khan, A. Towards digital economy: The development of ICT and E-commerce in Malaysia. Mod. Appl. Sci. 2011, 5, 171-178. [CrossRef]

29. Fang, C.; Yang, D.; Meiyan, W. Employment and Inequality Outcomes in China; Citeseer: Princeton, NJ, USA, 2009.

30. Huang, W.-H.; Lin, Y.-J.; Lee, H.-F. Impact of population and workforce aging on economic growth: Case study of Taiwan. Sustainability 2019, 11, 6301. [CrossRef]

31. Yakubu, M.M.; Akanegbu, B.N.; Jelilov, G. Labour Force participation and economic growth in Nigeria. Adv. Manag. Appl. Econ. 2020, 10, 1-14.

32. Elkhalek, A.M.A.A. Economic development and participation of women in services sector: Empirical evidence from Egypt. Int. J. Financ. Econ. 2019, 11, 155-164. [CrossRef]

33. Rama, M. Globalization and workers in developing countries. J. Stat. Soc. Inq. Soc. Irel. 2013. [CrossRef]

34. Jenkins, R.O. Globalization, FDI and employment in Vietnam. Transnatl. Corp. 2006, 15, 115-142.

35. Ioan, D. Employment—cause and effect of the economic growth. Procedia Econ. Financ. 2014, 8, 268-274. [CrossRef]

36. Cyrek, M.; Fura, B. Employment for sustainable development: Sectoral efficiencies in EU countries. Soc. Indic. Res. 2019, 143, 277-318. [CrossRef]

37. Flinn, C.J.; Heckman, J.J. Models for the Analysis of Labor Force Dynamics; Working Paper; National Bureau of Economic Research: Cambridge, MA, USA, 1982; pp. 1-94.

38. Chen, W.; Niebel, T.; Saam, M. Are intangibles more productive in ICT-intensive industries? Evidence from EU countries. Telecommun. Policy 2016, 40, 471-484. [CrossRef]

39. Erumban, A.A.; Das, D.K. Information and communication technology and economic growth in India. Telecommun. Policy 2016, 40, 412-431. [CrossRef]

40. Botezatu, M.A. Organizational Sustainability, Modern Management and IT\&C Impact on Local Development. In Proceedings of the International E-Conference "Enterprises in the Global Economy", Timisoara, Romania, 14 October 2019.

41. Atasoy, H.; Banker, R.D.; Pavlou, P.A. On the longitudinal effects of IT use on firm-level employment. Inf. Syst. Res. 2016, 27, 6-26. [CrossRef]

42. Khan, A.G. Electronic commerce: A study on benefits and challenges in an emerging economy. GJMBR B Econ. Commer. 2016, 16, 255-259.

43. Hecker, D.E. Employment impact of electronic business. Mon. Labor Rev. 2001, 124, 3-16.

44. Terzi, N. The impact of e-commerce on international trade and employment. Procedia Soc. Behav. Sci. 2011, 24, 745-753. [CrossRef]

45. Singh, S. Impact of internet and E-commerce on the labour market. Indian J. Ind. Relat. 2008, 43, 633-644.

46. Jocevski, M.; Ghezzi, A.; Arvidsson, N. Exploring the growth challenge of mobile payment platforms: A business model perspective. Electron. Commer. Res. Appl. 2020, 40, 100908. [CrossRef]

47. Ksenija, D.; Anita, P.; Irena, P. Internet banking usage in selected european countries: Multiple regression analysis approach. In Proceedings of the 12th International Symposium on Operational Research, Dolenjske Toplice, Slovenia, 25-27 September 2013; pp. 239-244.

48. Domadenik, P.; Koman, M.; Redek, T. SHAPING the Future: Opportunities and Challenges of E-Commerce; Časnik Finance: Ljubljana, Slovenia, 2018.

49. Bilerman, M.; Chua, J.; Guy, A.; McShane, K. Technology at Work v3.0: Automating E-Commerce from Click to Pick to Door; Citi GPS: Global Perspectives \& Solutions, Oxford Martin School and Citi: Oxford, UK, 2017. 
50. Bram, J.; Gorton, N. How Is Online Shopping Affecting Retail Employment? Federal Reserve Bank: New York, NY, USA, 2017.

51. Turban, E.; Outland, J.; King, D.; Lee, J.K.; Liang, T.-P.; Turban, D.C. Electronic Commerce 2018. A Managerial and Social Networks Perspective; Springer International Publishing: Cham, Switzerland, 2018.

52. Meyersohn, N. Amazon Will Hire 125,000 Workers, Dangling $\$ 3000$ Bonuses for Some Jobs. Available online: https: / edition.cnn. com/2021/09/14/business/amazon-hiring-jobs/index.html (accessed on 25 September 2021).

53. Zandi, M.; Koropeckyj, S.; Singh, V.; Matsiras, P. The Impact of Electronic Payments on Economic Growth; Moody's Corporation: New York, NY, USA, 2016.

54. Sedighi, A.; Sirang, B. The effect of E-commerce on SME performance. Int. J. Appl. Res. Manag. Econ. 2018, 1, 71-81.

55. Jovanović, J.Š.; Vujadinović, R.; Mitreva, E.; Fragassa, C.; Vujović, A. The relationship between E-commerce and firm performance: The mediating role of internet sales channels. Sustainability 2020, 12, 6993. [CrossRef]

56. Americo, A.; Veronico, A. The Effect of E-Commerce on Employment in Retail Sector; Mimeo: New York, NY, USA, 2018.

57. Han, H.; Trimi, S. Social commerce design: A framework and application. J. Theor. Appl. Electron. Commer. Res. 2017, 12, 50-68. [CrossRef]

58. Huang, Z.; Benyoucef, M. From e-commerce to social commerce: A close look at design features. Electron. Commer. Res. Appl. 2013, 12, 246-259. [CrossRef]

59. Yun, Z.-S. Testing a Theoretical Model to Examine the Relationships Among E-Social Shopping Motivation, Perception, and Behavioral Intention; Michigan State University Retailing: East Lansing, MC, USA, 2011.

60. Shafiee, M.M.; Bazargan, N.A. Behavioral customer loyalty in online shopping: The role of E-service quality and E-recovery. J. Theor. Appl. Electron. Commer. Res. 2018, 13, 26-38. [CrossRef]

61. Fidan, H. Grey relational classification of consumers' textual evaluations in E-commerce. J. Theor. Appl. Electron. Commer. Res. 2020, 15, 48-65. [CrossRef]

62. Gyenge, B.; Máté, Z.; Vida, I.; Bilan, Y.; Vasa, L. A new strategic marketing management model for the specificities of E-commerce in the supply chain. J. Theor. Appl. Electron. Commer. Res. 2021, 16, 64. [CrossRef]

63. Sumanjeet. Social implications of electronic commerce. J. Soc. Sci. 2009, 21, 91-97. [CrossRef]

64. Chen, L. Retailers' differentiation strategy and pricing in the rental market of digital content: A case of E-textbooks. J. Theor. Appl. Electron. Commer. Res. 2019, 14, 61-75. [CrossRef]

65. Meghisan-Toma, G.-M.; Puiu, S.; Florea, N.M.; Meghisan, F.; Doran, D. Generation Z' young adults and M-commerce use in Romania. J. Theor. Appl. Electron. Commer. Res. 2021, 16, 82. [CrossRef]

66. Statista. Mobile Retail Commerce Sales as Percentage of Retail E-Commerce Sales Worldwide from 2016 to 2021 . Available online: https:/ / www.statista.com/statistics/806336/mobile-retail-commerce-share-worldwide/ (accessed on 26 March 2021).

67. Savvy, M. Global Mobile eCommerce Statistics, Trends \& Forecasts. Available online: https://www.merchantsavvy.co.uk/mobileecommerce-statistics / (accessed on 26 March 2021).

68. Lipsman, A. Global Ecommerce 2019. Available online: https://www.emarketer.com/content/global-ecommerce-2019 (accessed on 15 July 2021).

69. Boateng, R.; Heeks, R.; Molla, A.; Hinson, R. E-commerce and socio-economic development: Conceptualizing the link. Internet Res. 2008, 18, 562-594. [CrossRef]

70. Oliver Wyman. Is E-Commerce Good for Europe? Economic and Environmental Impact Study; Oliver Wyman: New York, NY, USA, 2021; pp. 1-119.

71. Gala, P.; Camargo, J.; Freitas, E. Economic Commission for Latin America and the Caribbean (ECLAC). Electron. Commer. Int. Trade Employ. Rev. Issues 2002, 3, 633-651.

72. Aydin, E.; Kavaklioglu, S. A study of superiority of e-trade compared to traditional methods of commerce in overcoming crises: Case study of kitapix.com. Procedia Soc. Behav. Sci. 2011, 24, 123-137. [CrossRef]

73. ElFadily, S.; Kaddar, A. Modeling and mathematical analysis of labor force evolution. Model. Simul. Eng. 2019, 2019, 1-5. [CrossRef]

74. Stanila, L.; Andreica, M.E.; Cristescu, A. Econometric analysis of the employment rate for the E.U. countries. Procedia Soc. Behav. Sci. 2019, 109, 178-182. [CrossRef]

75. Elhorst, J.P.; Zeilstra, A.S. Labour force participation rates at the regional and national levels of the European Union: An integrated analysis. Pap. Reg. Sci. 2007, 86, 525-549. [CrossRef]

76. Botha, I.; Botezatu, M.A.; Coanca, M. Innovative calculation model for evaluating regional sustainable development. Econ. Comput. Econ. Cybern. Stud. Res. 2020, 54, 5-24. [CrossRef]

77. Vega, S.H.; Elhorst, J.P. Regional labour force participation across the European Union: A time-space recursive modelling approach with endogenous regressors. Spat. Econ. Anal. 2017, 12, 138-160. [CrossRef]

78. Nekrep, A.; Strašek, S.; Boršič, D. Productivity and Economic Growth in the European Union: Impact of Investment in Research and Development. Naše Gospod. Our Econ. 2018, 64, 18-27. [CrossRef]

79. Gocer, I.; Alatas, S.; Peker, O. Effects of R\&D and innovation on income in EU countries: New generation panel cointegration and causality analysis. Theor. Appl. Econ. 2016, 23, 153-164.

80. Ho, Y.P.; Wong, P.K.; Toh, M.H. The impact of R\&D on the Singapore economy: An empirical evaluation. Singap. Econ. Rev. 2009, 54, 1-20. [CrossRef] 
81. Miroslava, V.; Borisb, M.; Olgac, I.; Mitjad, Č. R\&D and economic growth in Slovenia: A dynamic general equilibrium approach with endogenous growth. Panoeconomicus 2011, 58, 67-89. [CrossRef]

82. Ali-Yrkkö, J. Impact of Public RED Financing on Employment; The Research Institute of the Finnish Economy (ETLA): Helsinki, Finland, 2005.

83. Dortet-Bernadet, V.; Sicsic, M. The effect of R\&D subsidies and tax incentives on employment: An evaluation for small firms in France. Econ. Stat. 2017, 493, 5-22. [CrossRef]

84. Bong, K.H.; Park, S.; Park, J. What types of public R\&D support increase employment performance? Evidence from Korean firm-level data. Appl. Econ. Lett. 2020, 27, 673-678. [CrossRef]

85. Thomson, R.; Jensen, P. The effects of government subsidies on business R\&D employment: Evidence from OECD countries. Natl. Tax. J. 2013, 66, 281-310. [CrossRef]

86. Ciarli, T.; Marzucchi, A.; Salgado, E.; Savona, M. The Impact of RED on Employment and Self-Employment Composition in Local Labour Markets; Working Paper; European Union: Brussels, Belgium, 2018; pp. 1-42.

87. Hsiao, C. Panel data analysis—advantages and challenges. TEST 2007, 16, 1-22. [CrossRef]

88. Blundell, R.; Mátyás, L. Panel data analysis: An introductory overview. Struct. Change Econ. D 1992, 3, 291-299. [CrossRef]

89. Baltagi, B.H. Econometric Analysis of Panel Data, 6th ed.; Springer: Cham, Switzerland, 2021.

90. Shaik, I.; Nittela, S.S.; Hiwarkar, T.; Nalla, S. K-means Clustering Algorithm Based on E-Commerce Big Data. IJITEE 2019, 8, 1910-1914. [CrossRef]

91. Jain, A.K. Data clustering: 50 years beyond K-means. Pattern Recognit. Lett. 2010, 31, 651-666. [CrossRef]

92. Blömer, J.; Lammersen, C.; Schmidt, M.; Sohler, C. Theoretical Analysis of the k-Means Algorithm-A Survey. In Algorithm Engineering: Selected Results and Surveys; Kliemann, L., Sanders, P., Eds.; Springer International Publishing: Cham, Switzerland, 2016.

93. Hausman, J.A. Specification tests in econometrics. Econometrica 1978, 46, 1251-1271. [CrossRef]

94. Machado, J.A.F.; Silva, J.M.C.S. Quantiles via moments. J. Econom. 2019, 213, 145-173. [CrossRef]

95. Koenker, R. Quantile regression for longitudinal data. J. Multivar. Anal. 2004, 94, 74-89. [CrossRef]

96. Canay, I.A. A simple approach to quantile regression for panel data. Econom. J. 2011, 14, 368-386. [CrossRef]

97. Ecommerce Europe. Impact of the Coronavirus on E-Commerce; Survey Results Report, 21 January 2021; Ecommerce Europe: Brussels, Belgium, 2021; pp. 1-12.

98. Ecommerce Europe. Impact of the Coronavirus on E-Commerce; Survey Results Report, 14 May 2020; Ecommerce Europe: Brussels, Belgium, 2020; pp. 1-45.

99. Euromonitor. E-Commerce in Western Europe. 2020. Available online: https://www.euromonitor.com/e-commerce-in-westerneurope/report (accessed on 28 September 2021).

100. eMarketer. Western Europe to See $\$ 10.83$ Billion More in Ecommerce Sales than Expected. Available online: https://www. emarketer.com/content/western-europe-see-10-83-billion-more-ecommerce-sales-than-expected (accessed on 28 September 2021).

101. International Trade Administration. Ireland-Country Commercial Guide. Available online: https://www.trade.gov / knowledgeproduct/ireland-ecommerce (accessed on 28 September 2021).

102. JP Morgan. E-Commerce Payments Trends: Ireland. Available online: https://www.jpmorgan.com/europe/merchant-services/ insights/reports/ireland (accessed on 28 September 2021).

103. JP Morgan. 2020 E-Commerce Payments Trends Report: Denmark. Available online: https://www.jpmorgan.com/merchantservices/insights/reports/denmark-2020 (accessed on 28 September 2021).

104. Ecommercenews. Ecommerce in Denmark. Available online: https://ecommercenews.eu/ecommerce-in-europe/ecommerce-indenmark/ (accessed on 28 September 2021).

105. Nordea. E-Commerce in Sweden. Available online: https://www.nordeatrade.com/en/explore-new-market/sweden/ecommerce (accessed on 28 September 2021).

106. PostNord. E-Commerce in Europe 2020; PostNord: Stockholm, Sweden, 2020.

107. Mandel, M. How E-commerce is raising pay and creating jobs around the country. Forbes 2017, 11, 2019. Available online: https: / / www.forbes.com/sites/realspin/2017/04/03/how-e-commerce-is-raising-pay-and-creating-jobs-around-thecountry /?sh=4f1db0c26dff (accessed on 28 September 2021).

108. Rugaber, C.S. Why the explosive growth of e-commerce could mean more jobs. Denver Post, 29 October $2017 ; 1$.

109. Mandel, M. How Ecommerce Creates Jobs and Reduces Income Inequality; Progressive Policy Institute: Washington, DC, USA, 2007; Volume 3.

110. Liao, D.; Valliant, R. Variance inflation factors in the analysis of complex survey data. Surv. Methodol. 2012, 38, 53-62.

111. O'brien, R.M. A caution regarding rules of thumb for variance inflation factors. Qual. Quant. 2007, 41, 673-690. [CrossRef]

112. Gujarati, D.N. Basic Econometrics, 4th ed.; Tata McGraw Hill: New York, NY, USA, 2004.

113. Kleinbaum, D.G.; Kupper, L.L.; Nizam, A.; Rosenberg, E.S. Applied Regression Analysis and Other Multivariable Methods; Cengage Learning: Boston, MA, USA, 2014. 